\title{
Phenolic metabolites in the resistance of northern forest trees to pathogens - past experiences and future prospects
}

\author{
Johanna Witzell and Juan A. Martín
}

\begin{abstract}
Phenolic metabolites are frequently implicated in chemical defense mechanisms against pathogens in woody plants. However, tree breeding programmes for resistance to pathogens and practical tree-protection applications based on these compounds seem to be scarce. To identify gaps in our current knowledge of this subject, we explored some of the recent literature on the involvement of phenolic metabolites in the resistance of northern forest trees (Pinus, Picea, Betula, Populus, and Salix spp.) to pathogens. Although it is evident that the phenolic metabolism of trees is often activated by pathogen attacks, few studies have convincingly established that this induction is due to a specific defense response that is capable of stopping the invading pathogen. The role of constitutive phenolics in the resistance of trees to pathogens has also remained unclear. In future studies, the importance of phenolics in oxidative stress, cell homeostasis and tolerance, and the spatial and temporal localization of phenolics in relation to invading pathogens should be more carefully acknowledged. Possibilities for future studies using advanced methods (e.g., metabolic profiling, confocal laser scanning microscopy, and use of modified tree genotypes) are discussed.
\end{abstract}

Résumé : Les métabolites phénoliques sont souvent impliqués dans les mécanismes de défense chimiques contre les agents pathogènes chez les plantes ligneuses. Cependant, il semble y avoir peu de programmes d'amélioration des arbres pour la résistance aux agents pathogènes ou de mesures pratiques de protection des arbres qui sont basés sur ces composés. Dans le but d'identifier les lacunes dans nos connaissances actuelles sur ce sujet, nous avons exploré une partie de la littérature récente traitant du rôle des métabolites phénoliques dans la résistance des espèces forestières nordiques (Pinus, Picea, Betula, Populus et Salix spp.) aux agents pathogènes. Bien qu'il soit évident que le métabolisme des composés phénoliques chez les arbres est souvent déclenché par les attaques des agents pathogènes, il a rarement été établi de façon convaincante que cette induction est due à une réaction de défense spécifique capable d'enrayer l'invasion de l'agent pathogène. De plus, on n'est toujours pas certain du rôle que jouent les composés phénoliques constitutifs dans la résistance des arbres face aux agents pathogènes. Dans les études ultérieures, on devrait accorder plus d'attention à l'importance des composés phénoliques en lien avec le stress oxydatif, l'homéostasie et la tolérance des cellules ainsi qu'à la localisation spatiale et temporelle des composés phénoliques en relation avec l'invasion des agents pathogènes. La discussion porte sur la possibilité que les études futures utilisent des méthodes de pointes telles que le profilage métabolique, le microscope confocal à balayage laser et aient recours à des arbres dont le génotype a été modifié.

[Traduit par la Rédaction]

\section{Introduction}

The chemical quality of plants is an important determinant of their resistance to natural enemies. In this context, the most intensively studied phytochemicals are the socalled secondary metabolites, including phenolics. Phenolic metabolites have frequently been linked to defense mechanisms of plants against natural enemies, such as pathogenic fungi (Hammerschmidt 2005). Most convincing evidence supporting the antifungal functions of phenolics originates from studies with herbaceous plants, such as tobacco, for which advanced molecular methods have long been available (Maher et al. 1994). In woody plants phenolics have been studied as markers for resistance to pathogens. Nevertheless, tree breeding programmes for resistance to pathogens and practical tree-protection applications based on these compounds seem to be scarce. In recent years, molecular techniques have become increasingly applicable to woody plants (Peña and Séguin 2001; Jansson and Douglas 2007). These molecular techniques, together with the in-

Received 7 April 2008. Accepted 8 July 2008. Published on the NRC Research Press Web site at cjfr.nrc.ca on 3 October 2008.

J. Witzell. ${ }^{1}$ Southern Swedish Forest Research Centre, Swedish University of Agricultural Sciences, 23053 Alnarp, Sweden.

J.A. Martín. Anatomía, Fisiología y Genética Forestal, ETSI de Montes, Universidad Politécnica de Madrid, Ciudad Universitaria s/n, 28040 Madrid, Spain.

${ }^{1}$ Corresponding author (e-mail: johanna.witzell@ess.slu.se). 
creased availability of high-throughput analysis methods (e.g., metabolic profiling approach; Fiehn 2002), have opened up completely new prospects for tree-pathogen studies. Thus, the research concerning the role of phenolics in tree-pathogen interactions has entered a new era. At this stage, it is valuable to summarize the knowledge acquired from studies done with traditional approaches. Here, we reviewed some of the recent studies concerning the role of phenolic metabolites in the interactions between economically important boreal forest tree species and their pathogens. Our aim was to identify gaps in our knowledge, and to point out some central questions for the future studies using the recent techniques in molecular biology, microscopy, and chemical analyses.

\section{Scope of the review and limitations of the literature covered}

In this review, the main focus was on soluble phenolics with relatively low molecular weight, and only specific aspects about larger phenolic molecules have been included. It is, however, important to keep in mind that in the context of pathogen defence these larger molecules, such as lignin, which is composed of phenolic units, and suberin, which can contain up to $50 \%$ phenolic material, play a significant role (e.g., Woodward 1992). The literature covered was restricted to a selection of papers published mainly during the last 10 years, dealing with coniferous and deciduous tree species that dominate the tree layers of boreal forests, including representatives of the genera Pinus (pines; including Austrian pine (Pinus nigra), native to southern Europe and western Asia), Picea (spruce), Betula (birch), Populus (poplar), and Salix (willow). Because our literature review was limited, our conclusions cannot be extended to all temperate zone woody plants. However, the selected literature draws attention to several interesting topics. Articles were selected from the database of ISI Web of Knowledge (Food Science and Technology Abstracts, Web of Science, BIOSIS Previews, CAB Abstracts) by conducting searches that combined the scientific names of the selected tree and pathogen species with the keywords "resistance" or "defense-defence" and "phenolics". Abstracts and reference lists of over 200 publications were studied in greater detail. Within the sections that follow, the literature concerning conifers is described first, followed by literature concerning angiosperms. For an overview, a set of representative studies was organized according to tree taxonomy, phenolic compound and compound class, studied plant organ, pathogen species, and role of the studied phenolics in resistance. Studies were divided into three categories: those that address constitutive compounds (Table 1); those that address pathogen-induced compounds (local or systemic; Table 2), and those that present in vitro effects of phenolics on pathogens (Table 3).

\section{Phenolic metabolites and resistance of northern trees to pathogens}

In this section, the possible involvement of constitutive (preformed) and inducible phenolic metabolites in the defense of northern forest trees against fungal pathogens, the most important group of tree pathogens, is discussed. Here, we assume that field studies correlating phenolic concentrations with pathogen frequencies deal mainly with constitutive concentrations of phenolics. However, we do recognize that several defensive chemicals that are present at measurable concentrations before a pathogen attack can be induced by an attack ("phytoanticipins" sensu VanEtten et al. 1994), and that it is difficult to separate the constitutive and induced concentrations because the induction history of trees in field studies is unknown. Thus, we use the group labels "constitutive" and "induced" in a pragmatic way, bearing in mind that the biological basis for these groupings may be imprecise.

\section{Constitutive phenolics}

Pines and spruces contain a variety of secondary metabolites, including resin acids, terpenes, and phenolics, all of which have been implicated in resistance against natural enemies (Honkanen et al. 1999; Sallas et al. 2001). In Scots pine (Pinus sylvestris), the stilbenes pinosylvin (PS) and pinosylvin monomethylether (PSME) occur constitutively in the heartwood. These chemicals are likely involved in the considerable resistance of pine heartwood against fungal colonization, probably as a result of their dual activity as fungicides and antioxidants (Bergström et al. 1999; Schultz and Nicholas 2000; Venäläinen et al. 2003). Flavonoids, such as taxifolin and its glucoside, occur constitutively in Scots pine phloem tissues and have been related to reaction efficiency against the bark beetle associated fungi Ophiostoma brunneo-ciliatum and Leptographium wingfieldii (Lieutier et al. 1996; Bois and Lieutier 1997). The phloem of Picea spp. also contains stilbenes such as astringin and isorhapotin, acetophenone picein, and flavonoids such as taxifolin glucoside and (+)-catechin (e.g., Lieutier et al. 2003). High constitutive concentrations of isorhapontin have been related to enhanced Norway spruce (Picea abies) resistance to the blue-stain fungus Ceratocystis polonica, and high constitutive phenol diversity has been proposed as a potential predictor of resistance (Brignolas et al. 1998; Lieutier et al. 2003). In Sitka spruce (Picea sitchensis), no consistent correlation between constitutive concentrations of bark stilbene glucosides and resistance to colonization by the root- and butt-rot fungi Heterobasidion annosum and Phaeolus schweinitzii was found by Toscano Underwood and Pearce (1992). The authors suggested that the principal role of bark stilbenes may be nonspecific protection, which may contribute to resistance against unspecialized pathogens (see also Pearce 1996b).

Birches and Salicicaceae species (Populus spp., Salix spp.) are economically valuable deciduous trees for largescale commercial exploitation in northern forests. In birch, the major group of leaf phenolics is composed of tannins, especially condensed tannins (proanthocyanidins), which may constitute over $10 \%$ of the dry mass. Birches are also rich in hydrolysable tannins (gallotannins), phenolic glucosides, flavonoids, and triterpenoids (Salminen et al. 2001; Riipi et al. 2002). Leaf tissues in poplars and willows are mainly characterized by low molecular weight phenolic glucosides and condensed tannins (Hakulinen et al. 1999; Osier and Lindroth 2001).

The constitutive methanol-soluble phenolics, such as the flavan-3-ol (+)-catechin, have been studied as potential 
Table 1. Examples of constitutive phenolic compounds of selected timber and landscape trees and their suggested role in resistance against pathogens.

\begin{tabular}{|c|c|c|c|c|c|c|c|}
\hline Tree & Pathogen & Phenolic compounds ${ }^{a}$ & $\begin{array}{l}\text { Type of } \\
\text { phenolics }^{b}\end{array}$ & $\begin{array}{l}\text { Plant part or } \\
\text { tissue }\end{array}$ & $\begin{array}{l}\text { Analysis } \\
\text { method }^{c}\end{array}$ & $\begin{array}{l}\text { Role in } \\
\text { resistance }^{d}\end{array}$ & Reference(s) \\
\hline \multirow[t]{6}{*}{ Pinus sylvestris } & Coniophora puteana & PS, PSME & $\mathrm{S}$ & Heartwood & HPLC & + & Venäläinen et al. 2003 \\
\hline & Ophiostoma brunneo-ciliatum & Taxifolin & $\mathrm{F}$ & Phloem & HPLC, TLC & + & Lieutier et al. 1996 \\
\hline & & Taxifolin glucoside & $\mathrm{F}$ & & & - & \\
\hline & & p-Coumaric acid esters & $\mathrm{HCA}$ & & & - & \\
\hline & & Acetophenone glycoside & $\mathrm{AcPh}$ & & & - & \\
\hline & Leptographium wingfieldii & Taxifolin glycoside & $\mathrm{F}$ & & HPLC & + & Bois and Lieutier 1997 \\
\hline \multirow[t]{7}{*}{ Picea abies } & Ceratocystis polonica & Isorhapotin & S & & HPLC & - & $\begin{array}{l}\text { Brignolas et al. 1998; } \\
\text { Lieutier et al. } 2003\end{array}$ \\
\hline & & Astringin & S & & & $\mathrm{n}$ & \\
\hline & & Picein & $\mathrm{AcPh}$ & & & $\mathrm{n}$ & \\
\hline & & Taxifolin glycoside & $\mathrm{F}$ & & & $\mathrm{n}$ & \\
\hline & & $(+)$-Catechin & $\mathrm{F}$ & & & $\mathrm{n}$ & \\
\hline & Sirococcus conigenus & Picein & $\mathrm{AcPh}$ & Needles & HPLC & + & Bahnweg et al. 2000 \\
\hline & & (+)-Catechin & $\mathrm{F}$ & & & + & \\
\hline \multirow[t]{2}{*}{ Picea sitchensis } & $\begin{array}{l}\text { Heterobasidion annosum, } \\
\text { Phaeolus schweinitzii }\end{array}$ & Isorhapotin & $S$ & Bark & HPLC & $\mathrm{n}$ & $\begin{array}{l}\text { Toscano-Underwood } \\
\text { and Pearce } 1992\end{array}$ \\
\hline & & Astringin & $\mathrm{S}$ & & & $\mathrm{n}$ & \\
\hline \multirow[t]{7}{*}{ Populus tremuloides } & Phellinus tremulae & Benzoic acid & $\mathrm{PhA}$ & Stem (galls) & $\begin{array}{l}\text { GC, MS, NMR, } \\
\text { TLC, FT-IR, FC }\end{array}$ & + & Pausler et al. 1995 \\
\hline & & p-Hydroxybenzoic acid & $\mathrm{PhA}$ & & & $\mathrm{n}$ & \\
\hline & & Trans-cinnamic acid & $\mathrm{HCA}$ & & & $\mathrm{n}$ & \\
\hline & & p-Hydroxycinnamic acid & $\mathrm{HCA}$ & & & $\mathrm{n}$ & \\
\hline & & Naringenin & $\mathrm{F}$ & & & $\mathrm{n}$ & \\
\hline & & 7'-Methyl-3-hydronaringen & $\mathrm{F}$ & & & $\mathrm{n}$ & \\
\hline & & Taxifolin & $\mathrm{F}$ & & & $\mathrm{n}$ & \\
\hline \multirow[t]{5}{*}{ Salix myrsinifolia } & Melampsora sp. & $(+)$-Catechin & $\mathrm{F}$ & Leaf & HPLC & $(+)$ & $\begin{array}{l}\text { Hakulinen et al. 1999; } \\
\text { Hakulinen and } \\
\text { Julkunen-Tiitto } 2000\end{array}$ \\
\hline & & Luteolin-7-glucoside & $\mathrm{F}$ & & & $\mathrm{n}$ & \\
\hline & & Chlorogenic acid & $\mathrm{HCA}$ & & & $(+)$ & \\
\hline & & Salicin & $\mathrm{SaD}$ & & & $(+)$ & \\
\hline & & Salicortin & $\mathrm{SaD}$ & & & $\mathrm{n}$ & \\
\hline
\end{tabular}

${ }^{a} \mathrm{PS}$, pinosylvin; PSME, pinosylvin monomethylether.

${ }^{b} \mathrm{PhA}$, phenolic acids $\left(\mathrm{C}_{6}-\mathrm{C}_{1}\right)$; AcPh, acetophenone $\left(\mathrm{C}_{6}-\mathrm{C}_{2}\right)$; HCA, hydroxycinnamic acids $\left(\mathrm{C}_{6}-\mathrm{C}_{3}\right)$; $\mathrm{S}$, stilbenes $\left(\mathrm{C}_{6}-\mathrm{C}_{2}-\mathrm{C}_{6}\right)$; F, flavonoids $\left(\mathrm{C}_{6}-\mathrm{C}_{3}-\mathrm{C}_{6}\right)$; SaD, salicin derivatives; PP, polyphenolics.

${ }^{c}$ HPLC, high performance liquid chromatography; TLC, two-dimensional thin-layer chromatography; GC, mass chromatography; MS, mass spectrometry; NMR, nuclear magnetic resonance; FT-IR, Fourier transform infrared spectrometry; FC, flash chromatography.

${ }^{d}+$, high constitutive concentrations related to enhanced resistance; - , low constitutive concentrations related to enhanced resistance; $(+)$ high constitutive concentrations related in some cases to enhanced resistance; $\mathrm{n}$, no role in resistance. 
Table 2. Examples of pathogen induced responses in phenolic compounds in selected timber and landscape trees.

\begin{tabular}{|c|c|c|c|c|c|c|c|}
\hline Host & Pathogen & Induced phenolics ${ }^{a}$ & $\begin{array}{l}\text { Type of } \\
\text { phenolics }^{b}\end{array}$ & Response $^{c}$ & $\begin{array}{l}\text { Analysed plant part } \\
\text { or tissue }^{d}\end{array}$ & Analysis method ${ }^{e}$ & Reference(s) \\
\hline \multirow[t]{13}{*}{ Pinus sylvestris } & Heterobasidion annosum & PS, PSME & $\mathrm{S}$ & + & $\begin{array}{l}\text { L (roots), } \\
\text { S (needles) }\end{array}$ & HPLC, & Bonello et al. 1993 \\
\hline & & Lignin & PP & + & $\mathrm{L}$ (roots) & Spectrophotometry & \\
\hline & & Catechin & $\mathrm{F}$ & - & & & \\
\hline & Heterobasion parviporum & PS, PSME & $\mathrm{S}$ & + & $\begin{array}{l}\mathrm{L} \text { (stem and root } \\
\text { sapwood) }\end{array}$ & $\begin{array}{l}\text { HPLC, } \\
\text { histochemistry }\end{array}$ & Johansson et al. 2004 \\
\hline & $\begin{array}{l}\text { Ophiostoma } \\
\text { brunneo-ciliatum }\end{array}$ & PS, PSME & $\mathrm{S}$ & + & L (stem phloem) & HPLC, TLC & Lieutier et al. 1996 \\
\hline & & Pinocembrin & $\mathrm{F}$ & + & & & \\
\hline & & p-Coumaric acid esters & HCA & - & & & \\
\hline & & Acetophenone glycoside & HCA & - & & & \\
\hline & & Taxifolin & $\mathrm{F}$ & $+/-$ & & & \\
\hline & & Taxifolin glicoside & $\mathrm{F}$ & $+/-$ & & & \\
\hline & Leptographium wingfieldii & PS, PSME & $\mathrm{S}$ & + & & HPLC & Bois and Lieutier 1997 \\
\hline & & Pinocembrin & $\mathrm{F}$ & + & & & \\
\hline & & Taxifolin & $\mathrm{F}$ & + & & & \\
\hline \multirow[t]{8}{*}{ Pinus nigra } & $\begin{array}{r}\text { Sphaeropsis sapinea } \\
\quad(=\text { Diploidia pinea })\end{array}$ & PS, PSME & $\mathrm{S}$ & + & $\begin{array}{l}\text { L (stem phloem), } \\
\text { S (stem phloem) }\end{array}$ & HPLC & $\begin{array}{l}\text { Bonello and Blodgett } \\
2003\end{array}$ \\
\hline & & Taxifolin-like compound & $\mathrm{F}$ & + & & & \\
\hline & & Ferulic acid & $\mathrm{PhA}$ & - & & & \\
\hline & & Taxifolin & $\mathrm{F}$ & + & L (stem phloem) & & \\
\hline & & Naringenin-like compound & $\mathrm{F}$ & + & & & \\
\hline & & Lignin & PP & + & & & \\
\hline & & Catechin-like compound & $\mathrm{F}$ & - & & & \\
\hline & & Feruric acid glucoside & $\mathrm{PhA}$ & - & & & \\
\hline \multirow[t]{13}{*}{ Picea abies } & Ceratocystis polonica & Isorhapontigenin & $\mathrm{S}$ & + & L (stem phloem) & GC, MS & Viiri et al. 2001 \\
\hline & & Stilbene glycosides & $\mathrm{S}$ & - & & & \\
\hline & & $(+)$-Catechin & $\mathrm{F}$ & + & & HPLC & Brignolas et al. 1998 \\
\hline & Gremmeniella abietina & Phenolic acids & $\mathrm{PhA}$ & + & L (branch phloem) & $\begin{array}{l}\text { HPLC, } \\
\text { spectrophotometry }\end{array}$ & Cvikrová et al. 2006 \\
\hline & & p-Coumaric acid & HCA & + & & & \\
\hline & & Lignin & $\mathrm{PP}$ & + & & & \\
\hline & & p-Hydroxybenzoic acid & $\mathrm{PhA}$ & + & S (branch phloem) & & \\
\hline & Sirococcus conigenus & $(+)$-Catechin & $\mathrm{F}$ & + & $\mathrm{L}$ (needles) & HPLC & Bahnweg et al. 2000 \\
\hline & & Picein & $\mathrm{AcPh}$ & + & & & \\
\hline & & Isorhapontin & $\mathrm{S}$ & + & & & \\
\hline & & Astringin & $\mathrm{S}$ & + & & & \\
\hline & & Kaempferol-3-glucoside & $\mathrm{F}$ & + & & & \\
\hline & Pythium dimorphum & Lignin & PP & + & $\mathrm{L}($ root cortex $)$ & Histochemistry & Børja et al. 1995 \\
\hline Populus tremuloides & Entoleuca mammata & Lignin-like phenolics & $\mathrm{PP}$ & + & L (stem phloem) & & Bucciarelli et al. 1999 \\
\hline
\end{tabular}


markers for relative susceptibility of willows to Melampsora rusts (Hakulinen 1998). In greenhouse cultivated Salix myrsinifolia clones, high constitutive concentrations of (+)-catechin seemed to be linked to expression of rust resistance (Hakulinen et al. 1999). (+)-Catechin is a building block of condensed tannins, which have been found to correlate negatively with the frequency of Melampsora amygdalina rust on clones of Salix triandra, a willow species that is characterized by high constitutive concentration of condensed tannins (Hjältén et al. 2007a; see also the section Induced phenolics for information about induction of catechin in willows). In a 3 year field study, however, the association between concentration of (+)-catechin (or other phenolics) and rust frequency in Salix myrsinifolia clones was not evident (Hakulinen and Julkunen-Tiitto 2000).

Varying relationships have also been found between other pathogens and phenolics of northern deciduous trees. Trembling aspen (Populus tremuloides) bearing black stem galls was less likely to be damaged by Phellinus tremulae heartwood rot than non-gall-bearing trees (Crane et al. 1994). The galls are rich in benzoic acid, a low molecular weight phenolic (Pausler et al. 1995). Benzoic acid may be fungistatic itself, but it may also serve as a precursor for salicylic acid, which is involved in the induction of systemic resistance and hypersensitive response in plants (Ollerstam and Larsson 2003). In addition, quantitative differences in phenolic profiles of two aspen species (two hybrid aspen and two European aspen clones) were found to correlate well with the resistance of these species to aspen shoot blight (caused by Venturia tremulae) during one growth season (Freiwald 2008). However, altered concentrations of salicin derivatives and phenolic acids in hybrid aspen lines carrying antisense constructs of MYB genes were not accompanied by clear-cut alterations in the infection frequency of Venturia macularis (in vitro tests with incised leaves) (Witzell et al. 2005). In addition, the sapwood of willows and birches is highly susceptible to decay-causing fungi (Highley 1995; Schultz and Nicholas 2000), suggesting that the constitutive chemicals in the wood of these trees do not provide an effective defense against decay fungi.

In summary, the cited literature reveals that in most cases the role of preformed phenolics in the resistance of trees to pathogens has remained unclear (Table 1). Correlations between phenolic concentrations and disease symptoms in the field are not likely to be reliable unless confirmed by systematic, long-term studies. The lack of consistent correlations between constitutive phenolics and resistance of trees to pathogens indicates that the primary function of these compounds in trees may not be as directly fungitoxic compounds. Instead, they may contribute to resistance indirectly. For instance, some low molecular weight phenolic compounds may function as precursors for other defensive compounds (e.g., lignin; Bonello et al. 2003), or they may confer resistance as a group, rather than as individual compounds (Wallis et al. 2008). To better understand the role of phenolics in resistance of trees to pathogens, more studies that explore such possibilities are needed. It is also important to note that in addition to phenolics, or instead of them, terpenoids (and other metabolites) can be significant defenses against pathogens in many tree species. In the future, metabolic profiling may bring new information about the relative 
Table 3. Effect of phenolic compounds on in vitro growth of forest-tree pathogens in selected studies.

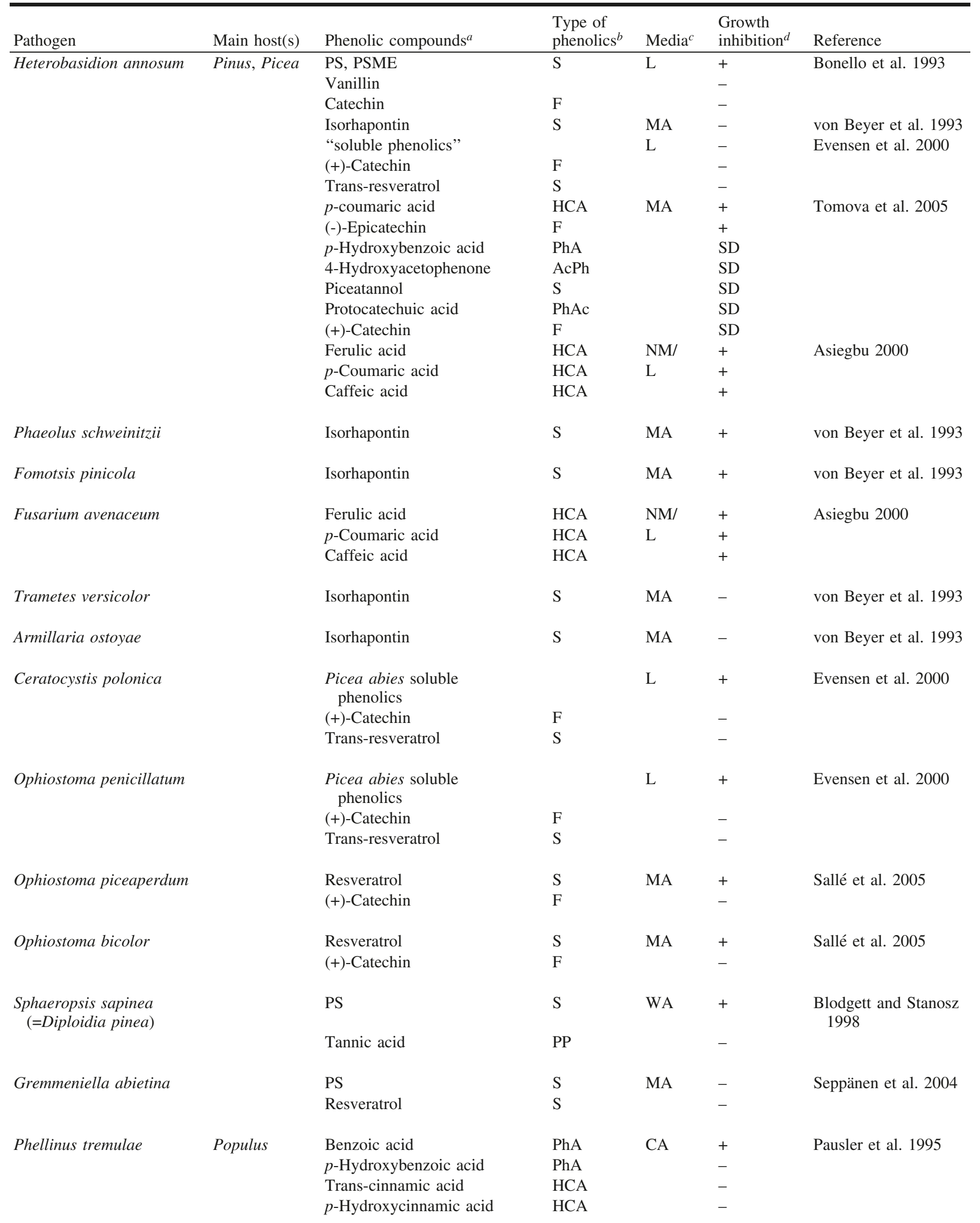


Table 3 (concluded).

\begin{tabular}{|c|c|c|c|c|c|c|}
\hline Pathogen & Main host(s) & Phenolic compounds ${ }^{a}$ & $\begin{array}{l}\text { Type of } \\
\text { phenolics }^{b}\end{array}$ & Media $^{c}$ & $\begin{array}{l}\text { Growth } \\
\text { inhibition }^{d}\end{array}$ & Reference \\
\hline & & Narigenin & $\mathrm{F}$ & & - & \\
\hline & & 7-Methyl-3-hydroxynaringen & $\mathrm{F}$ & & - & \\
\hline & & Taxifolin & $\mathrm{F}$ & & - & \\
\hline & & PS & $\mathrm{S}$ & & + & Seppänen et al. 2004 \\
\hline \multirow[t]{3}{*}{ Hypoxylon mammatum } & & Catechol & & TLC & + & $\begin{array}{l}\text { Kruger and Manion } \\
1994\end{array}$ \\
\hline & & Salicortin & $\mathrm{SaD}$ & & + & \\
\hline & & Salicin & $\mathrm{SaD}$ & & + & \\
\hline Piptoporus betulinus & Betula & PS & $\mathrm{S}$ & MA & + & Seppänen et al. 2004 \\
\hline \multirow[t]{2}{*}{ Pycnoporus cinnabarinus } & & PS & $\mathrm{S}$ & & + & \\
\hline & & Resveratrol & $\mathrm{S}$ & & - & \\
\hline \multirow[t]{2}{*}{ Pyrenopeziza betulicola } & & PS & $\mathrm{S}$ & & + & \\
\hline & & Resveratrol & $\mathrm{S}$ & & - & \\
\hline
\end{tabular}

${ }^{a} \mathrm{PS}$, pinosylvin; PSME, pinosylvin monomethylether.

${ }^{b} \mathrm{PhA}$, phenolic acids $\left(\mathrm{C}_{6}-\mathrm{C}_{1}\right) ; \mathrm{AcPh}$, acetophenones $\left(\mathrm{C}_{6}-\mathrm{C}_{2}\right) ; \mathrm{HCA}$, hydroxycinnamic acids $\left(\mathrm{C}_{6}-\mathrm{C}_{3}\right) ; \mathrm{S}$, stilbenes $\left(\mathrm{C}_{6}-\mathrm{C}_{2}-\mathrm{C}_{6}\right) ; \mathrm{F}$, flavonoids $\left(\mathrm{C}_{6}-\mathrm{C}_{3}-\mathrm{C}_{6}\right), \mathrm{SaD}$, salicin derivatives; $\mathrm{PP}$, polyphenolics.

'L, liquid medium; MA, malt agar; NM, Norkran's minimal medium; WA, water agar; CA, carrot agar; TLC, thin layer chromatography bioassay.

${ }^{d}+$, compound inhibited fungal growth; -, compound did not affected or enhanced fungal growth; SD, strain-dependent reaction.

importance of the different types of chemicals in resistance to pathogens. Moreover, molecular biology may provide new possibilities for targeted alterations in phenolic profiles of tree genotypes (cf. Witzell et al. 2005). By methodically testing such genotypes against an array of pathogens with varying modes of parasitism (biotrophs, necrotrophs), new information about the importance of individual constitutive phenolics for resistance of forest trees can be gained. Increasing attention needs to be given to the spatial aspects, i.e., compartmentalization of constitutive phenolics and their localization in relation to active pathogen structures (Marinova et al. 2007). For instance, although Tegelberg et al. (2001) found no connection between birch leaf flavonoids (extracted from macerated leaf samples) and the frequency of birch leaf rust, Valkama et al. (2005) reported significant negative correlations between the flavonoid aglycons on birch leaf surfaces and rust uredia. Techniques like in vivo histochemistry with confocal laser scanning microscopy (CLSM) should be valuable in such studies. This technique allows the identification of chemical components using their specific fluorescence characteristics, on the basis of their absorbance and emission behaviour. CLSM is particularly advantageous, since it permits the creation of three-dimensional images of thick samples. Thus, CLSM could be used to study the three-dimensional distribution of phenolic compounds around infection sites, or to obtain information about the subcellular localization of phenolic compounds (Hutzler et al. 1998).

\section{Induced phenolics}

In the context of induced defense mechanisms, many plant phenolics are thought to serve as phytoalexins, induced structural barriers, modulators of pathogenicity, and signalling molecules (Hammerschmidt 2005). Examples of phenolic metabolites related to induced defense of forest trees against fungi, as well as their suggested role in tree resistance, are summarized in Table 2. In the next paragraphs, results of selected, representative investigations are presented in greater detail.

Among the conifer phenolics, stilbenes have been most frequently studied in the context of induced resistance to pathogens. In Scots pine, the stilbenes PS and PSME, and several flavonoids often accumulate locally in the reaction zone after fungal infection (Lieutier et al. 1996; Bois and Lieutier 1997) and can be induced systemically in the needles (Bonello et al. 1993). These compounds were induced by different challenges (e.g., by wounding), indicating that the response was nonspecific. Quantitative modifications of the stilbene profile in Norway spruce trees after inoculation with Ceratocystis polonica have been reported, e.g., by Viiri et al. (2001). The concentrations of individual stilbene glycosides in the phloem decreased, while the concentration of the stilbene aglycone isorhapontigenin increased after inoculation, probably in response to $\beta$-glycosidase production by the fungus. Similar changes in the stilbene profile were produced by mechanical wounding, again suggesting a nonspecific response. In the same pathosystem, induced reactions 
to fungal inoculation or mechanical wounding were characterized by an increase in (+)-catechin concentrations, which was associated with an increase in tree resistance (Brignolas et al. 1998; Lieutier et al. 2003). However, no significant changes in isorhapontigenin or stilbene glycosides concentrations were found. In a recent study, Blodgett et al. (2007) found no correlation between the length of challenge lesions and PSME and concluded that stilbenes may not play a significant role in induced resistance against Sphaeropsis sapinea.

Johansson et al. (2004) compared the induced responses of Scots pine and Norway spruce after infection with the white rot fungi Heterobasidion annosum and Heterobasidion parviporum. Peroxidase activity was initially higher in spruce sapwood than in pine, but within 3 days of incubation the activity in spruce disappeared concurrently with deepening necrosis. In pine, there was a significant increase in peroxidase activity, and the inoculation with the two fungal species increased the amounts of PS, PSME, other phenolics, and resinous compounds. Peroxidases use the phenolic precursors for polymerizing and cross-linking reactions, which may retard further hyphal penetration (Perez et al. 2002 and references therein). Thus, the difference in oxidative metabolism that involves phenolics may contribute to the high resistance level of pine against Heterobasidion parviporum.

In Norway spruces infected with the ascomycete Gremmeniella abietina, the causal agent of stem canker and shoot dieback, accumulations of lignin, soluble and cell-wallbound phenolics, and increased total peroxidase activity were observed in bark tissues collected at the infection site (Cvikrová et al. 2006). Furthermore, pronounced accumulations of ester- and glycoside-bound benzoic acid derivatives were found in regions of infected branches that were not in contact with the pathogen, suggesting a systemic induction of phenylpropanoid metabolism (cf. Bonello et al. 2006; Blodgett et al. 2007). Evidence for the role of bark-associated phenolics in induced defense has also been gained from studies concerning polyphenolic parenchyma (PP) cells and conifer resistance (Franceschi et al. 2000, 2005). The PP cells are found constitutively in the secondary phloem of Pinaceae species, and after wounding or pathogen attack they release phenolics at the wound site (Franceschi et al. 1998, 2000; Hudgins et al. 2003; Krekling et al. 2004). Pretereatment inoculations of Norway spruce with Heterobasidion annosum, Nectria fuckeliana, and pathogenic Ceratocystis polonica isolates, causal agents of phloem necrosis, induced resistance against a subsequent mass inoculation with a pathogenic Ceratocystis polonica isolate and provided better protection than pretreatment with a nonpathogenic isolate of Ceratocystis polonica or malt agar (Krokene et al. 1999, 2001). Thus, necrosis that involves oxidation and polymerization of phenolic compounds seems to be important in priming the induction of resistance in Norway spruce. In Scots pine, on the other hand, induction of resistance was also found after mechanical wounding that only caused limited necrosis (Krokene et al. 2000). Thus, the involvement of phenolics in the initiation of induction may differ between pines and spruces.

The induction of phenolics by pathogens may occur locally, in tissues surrounding infection sites, but also systemically, in distal parts of a tree. While many studies have demonstrated that induction of phenolics occurs at a local scale (e.g., Krokene et al. 1999; Evensen et al. 2000; Franceschi et al. 2000), several recent studies have also found evidence for systemic induction of soluble low molecular weight phenolics and lignin (e.g., Bonello and Blodgett 2003; Bonello et al. 2006; Wallis et al. 2008). The activation of phenolic metabolism and the accumulation of certain phenolics appear to be commonly associated with the phenomenon referred to as systemic induced resistance to pathogens (SIR). SIR refers to a response in which an initial infection (or treatment with an inducing chemical agent) of a certain part of a plant leads to the activation of resistance mechanisms in distal parts of the same plant, thereby increasing the plant's resistance to subsequent infections (e.g., Bonello et al. 2006). Because of its great potential for sustainable disease control, SIR has been actively studied in herbaceous plant species and, in recent years, also in trees (Hammerschmidt 2003 and references therein). The studies with conifers clearly demonstrate that inducing treatments cause alterations in the concentrations of total phenolics, lignin, hydroxycinnamic acids, flavonoids, and stilbenes, but the direction and magnitude of these changes seem to vary depending on the compound, pathogen, host (species, age, plant part), and environment (Bonello and Blodgett 2003; Blodgett et al. 2005; Bonello et al. 2006; Wallis et al. 2008).

Studies with angiosperm trees have provided little evidence to support the hypothesis that induced low molecular weight phenolics play an active role in resistance to pathogens. For instance, one study reported accumulations of benzoic acid in trembling aspen trees bearing black stem galls (Pausler et al. 1995), but the compound's role in resistance to Phellinus tremulae heartwood rot remained unclear. In willows, leaf rusts induced changes in (+)-catechin metabolism (Hakulinen and Julkunen-Tiitto 2000), suggesting a mechanistic relationship between (+)-catechin and rust infection (Hakulinen et al. 1999). One such mechanism could be related to the role of (+)-catechin as a precursor of condensed tannins, for which antimicrobial activity via protein precipitation and iron depletion has been suggested (Scalbert 1991).

Like catechins, other phenolics with relatively low molecular weight, such as hydroxycinnamic acids, may act as precursors for larger molecules. Both in angiosperms and gymnosperms, the most important phenolic polymers in this context are lignin (Woodward 1992; Børja et al. 1995; Bonello and Blodgett 2003) and suberin (Pearce 1996a; Bernards 2002). Bucciarelli et al. (1999) compared histochemical responses in stem tissues of resistant and susceptible aspen genotypes inoculated with Entoleuca mammata, the causal agent of hypoxylon canker. In the resistant poplar clone the infection was first limited by the formation of an intact, lignified local zone around the infection site, and afterwards by development of a wound callus rich in phenolic substances. The susceptible genotype was impaired in its ability to mount these responses. These results suggest an important role of lignification in the defense strategy of aspen against E. mammata. The importance of lignification and suberization in defense and resistance has also been pointed out in studies with other angiosperms, such as elms (Rioux and Ouellette 1991; Martín et al. 2005a, 2005b, 2007). For instance, in elms infected with the Dutch elm disease pathogen, formation of suberized parenchyma cells 
and tyloses may help to maintain xylem function by restricting the pathogen spread (Martín et al. 2005b).

Although the induction of low molecular weight phenolics in trees after pathogen attack seems to be common, the relationship between phytoanticipin phenolics and resistance of trees to pathogens has often remained unclear (Blodgett et al. 2005; Bonello et al. 2006). Novel experimental and analytical approaches should be useful in further studies on this topic. The use of plant material of a priori unknown susceptibility may lead to small differences in disease reactions (Lieutier et al. 1996). In such cases it is difficult to ascertain the relevance of phenolics in terms of resistance. Studies on tree species that are amenable to vegetative propagation (e.g., Betulaceae and Salicaceae species) should use previously tested genotypes with contrasting or different degrees of disease susceptibility. If clonal propagation is not possible, the studied population has to be large enough to obtain a wide gradient of resistance level. An alternative to traditional screening methods is the use of signalling phytohormones (such as ethylene, jasmonates, or salicylic acid) that regulate plant defense responses (Hudgins and Franceschi 2004). Exogenously applying jasmonic or salicylic acid to certain conifers induces swelling of existing polyphenolic parenchyma cells, an increase in their phenolic contents, and the formation of additional PP cells and of traumatic resin ducts at the cambial zone (Franceschi et al. 2002; Hudgins et al. 2004; Zeneli et al. 2006). These phytohormones can be used to manipulate the biochemistry and anatomy of host trees and then to test their resistance to attack by pathogens and insects (e.g., Erbilgin et al. 2006; Zeneli et al. 2006). We may also have to reevaluate the actual mode of action of phenolics. Like constitutive phenolics, the role of induced phenolics may be strongly linked to their oxidative capacity. In a recent study, Ruuhola et al. (2008) found that oxidation of phenolics could be the actual mechanism explaining the rapidly induced resistance in mountain birch (Betula pubescens spp. czerepanovii) against defoliating autumnal moths. The same mechanism could be important in induced defense of trees against pathogens as well. This aspect is of particular interest considering that the speed of the host response is probably a crucial factor in determining the relative resistance among host genotypes. In future studies, simultaneous application of metabolomics and proteomics approaches (van Wijk 2001; Fiehn 2002) could be used to clarify whether oxidative reactions can explain the versatile responses of tree secondary metabolism in response to pathogen attacks.

\section{Antifungal activity of phenolic metabolites (in vitro effects)}

Results of recent studies that used in vitro tests for evaluating the effect of phenolic compounds against forest pathogens are summarized in Table 3 . In vitro tests are frequently used to complement studies with intact plant-parasite interactions. However, the biological significance of any information obtained from artificial systems has to be interpreted with caution, since the effect of plant chemicals against fungi in vitro may differ considerably from their effect or mode of action in vivo, and vice versa. For instance, in spite of the evidence relating high constitutive or inducible (+)catechin concentrations to tree resistance (see above), this compound has shown low antifungal effect against a broad range of pathogens (Heterobasidion annosum, Ophiostoma penicillatum, Ceratocystis polonica, Ophiostoma piceaperdum, and Ophiostoma bicolour) (Evensen et al. 2000; Sallé et al. 2005). Furthermore, Heterobasidion annosum is reportedly capable of catabolizing (+)-catechin very efficiently in vitro (Bonello et al. 1993).

Microenvironment and nutritional factors inside the plant tissues may affect fungal growth and a fungus's ability to overcome chemical defense mechanisms. Asiegbu (2000) provided evidence that cell-wall carbohydrates are important for the in vivo survival of fungi during initial stages of infection. He showed that cell-wall phenolics (ferulic acid, caffeic acid, and $p$-coumaric acid) inhibited growth of Heterobasidion annosum and Fusarium avenaceum, but the toxicity of these phenols was reversed in the presence the exogenously added cell-wall sugars glucose, fructose, sucrose, and cellobiose. The observation that carbohydrates from plant cells can restore active fungal growth suggests that this could be one of the ways these necrotrophs are able to compete with a plant's defense, and this strategy is probably advantageous for their parasitic mode of nutrition.

Pine stilbenes PS and PSME showed strong antifungal activity against Heterobasidion annosum (Bonello et al. 1993) and could be thus strictly considered as phytoalexin-like compounds. On the other hand, Evensen et al. (2000) found that Heterobasidion annosum was not negatively affected by any concentration of spruce phenolics. Furthermore, its growth was stimulated by the higher concentrations, suggesting that it was able to use spruce phenolics as sources of carbon. The stilbene isorhapontin showed antifungal activity against the brown-rot fungi Phaeolus schweinitzii and Fomitopsis pinicola, while it was ineffective against the white rot fungi Heterobasidion annosum, Trametes versicolor, and Armillaria ostoyae (von Beyer et al. 1993).

Among the different phenolics extracted from aspen black galls (Table 3), only benzoic acid showed antifungal activity against Phellinus tremulae (Pausler et al. 1995). Bioassays showed that the minimum inhibitory concentration of benzoic acid against Phellinus tremulae is within the range 800-1000 ppm, but the in vivo concentration of benzoic acid in galled trees was only about $90 \mathrm{ppm}$. Although the amount of benzoic acid in gall-bearing trees was insufficient to prevent fungal development, the role of benzoic acid as a salicylic acid precursor was suggested as a possible indirect cause of resistance. The aspen phenolics catechol, salicortin, and salicin were found to be inhibitory to Hypoxylon mammatum (Kruger and Manion 1994).

The divergent results from various in vitro tests indicate that the antifungal effectiveness of phenolics is highly compound specific and that there is species-specific variation in the sensitivity among fungi. In general, pathogens are likely to be highly adapted to the quality and quantity of phenolics of their hosts. For instance, Seppänen et al. (2004) showed that decay fungi of deciduous trees were more sensitive in vitro to high concentrations of PS, compared with decay fungi of conifers. However, Pyrenopeziza betulicola, a birch leaf spot pathogen, was relatively tolerant to PS (Seppänen et al. 2004). Differences in sensitivity-tolerance are likely to be explained by the differences in the array and activity of enzymes among fungi. For instance, laccase-producing 
white-rot fungi are reportedly able to inactivate stilbenes more effectively than brown-rot fungi that do not produce laccase (von Beyer et al. 1993; Evensen et al. 2000 and references therein). However, Seppänen et al. (2004) found that brown-rot fungi were more sensitive than white-rot fungi to PS in decay tests (on impregnated wood samples) but not in agar plate tests. This example illustrates the necessity to interpret results of in vitro tests with caution.

\section{Inherent and environmental factors modulating phenolic concentrations - effects on plant-parasite interactions}

\section{Variation in phenolics and resistance due to plant- inherent factors}

The genotype is a major intrinsic determinant of the defensive potential of a plant. Marked intraspecific variations in disease resistance (Elamo et al. 2000; Nagy et al. 2004), as well as in phenolic content (Hakulinen et al. 1999; Laitinen et al. 2005; Haviola et al. 2006), have been reported. For instance, the susceptibility of Norway spruce to Ceratocystis polonica has been shown to be under strong genetic control (Brignolas et al. 1998; Evensen et al. 2000). Factors affecting spruce resistance level, such as the initial number of polyphenolic parenchyma (PP) cells, their size, and the density of polyphenol bodies after infection, also seem to be under much stronger genetic than environmental control (Krekling et al. 2004; Nagy et al. 2004). Moreover, constitutive and inducible phenolics, such as (+)-catechin or taxifolin, were found to vary among spruce clones of different susceptibility to Ceratocystis polonica (Evensen et al. 2000). In Norway spruce needles, accumulation of the glucoside picein in response to inoculation with Sirococcus conigenus, which causes shoot blight and cankers of various conifers, was reported to depend on provenance (Bahnweg et al. 2000). The phenolic content seemed to be provenance and altitude dependent. Provenances from high altitudes (above $1000 \mathrm{~m}$ a.s.l.) contained higher concentrations of constitutive phenolics than those from low altitudes (below $500 \mathrm{~m}$ a.s.1.), while the low altitude provenances showed a strong induction of phenolics in response to infection (Bahnweg et al. 2000). This suggests that some forest trees may show genetic trade-offs between allocation to constitutive and induced phenolic responses to pathogens.

During plant development, secondary chemistry can change considerably, concomitantly with disease resistance level (Beare et al. 1999; Johnson and Kim 2005). In some cases, the concentration of phenolics has been found to be highest in young tissues and plant parts, whereas in others opposite trends have been reported (Hakulinen and Julkunen-Tiitto 2000; Johnson and Kim 2005). A strong ontogeny effect on phenolic metabolism has also been observed in the hybrid Populus trichocarpa $\times$ Populus deltoides (Johnson and Kim 2005). The authors suggested that phenolic compounds that were likely to contribute to Melampsora medusae rust immunity were present in immature leaves. In birch, however, the main phenolic compounds were found to be the same in both mature trees and clonal plantlets of the same trees (Laitinen et al. 2005), and most of the variation was explained by differences among parental trees, indicating genetic control of phenolic compounds.
To summarize, recent investigations have demonstrated considerable inherent variation among trees in their constitutive phenolic concentrations, in their induced phenolic responses to infection, and in their resistance. In most cases it has been difficult to establish a convincing link between the genetic variation in phenolics and resistance. This difficulty is likely due to the modifying effects of the environment (see below), the varying degree of physiological integrity among branches (i.e., repeated structural modules in trees), and the vascular sectoriality (Zanne et al. 2006) within an individual tree (Haukioja and Koricheva 2000), as well as the spatially and temporally dynamic development of plantpathogen interactions. The great variation in the concentrations of individual plant phenolics in response to pathogens and in the sensitivity of microorganisms to individual compounds may act as an effective buffer against any largescale environmental effects on the resistance of trees at the population level. The synchrony between the stages at which a host plant or plant part is susceptible to infection and the spore-producing stages of parasites often appears to be crucial to the success or failure of infection, but most studies have not been able to establish whether age-related differences in susceptibility to pathogens are a result of differences in phenolic contents. To confirm the possible links between ontogenic and phenological variation in phenolics and resistance to pathogens in forest trees, more systematic research on different tree-pathogen interactions is needed. In this context, new insights can be gained by comparative analyses of the phenolic profiles and resistance in trees that have been genetically modified by their developmental traits (Srivastava et al. 2007).

\section{The effect of abiotic environmental factors}

Natural variation in the abiotic environment (e.g., soil fertility, moisture, temperature, altitude) may profoundly modify the chemical basis and outcome of interactions between plants and their pathogens. In addition to natural environmental variation, plants have to cope with a variety of human-induced environmental changes, the rate and magnitude of which have greatly increased during the last decades. Human-induced alterations in the abiotic environment may have a significant impact on the production and accumulation of phenolics in trees, with concomitant changes in the phenolic-based defense against natural enemies (Peñuelas and Estiarte 1998). Some of the most studied factors in this context (especially in relation to resistance of trees to herbivores) are fertilization, ultraviolet (UV) light, carbon dioxide (and warming), and ozone.

Several hypotheses have been formulated to explain the variation in plant defensive chemistry (see Stamp 2003 for a review). Many of these hypotheses have been tested using fertilization treatments, mainly with nitrogen $(\mathrm{N})$. Both the growth-differentiation balance hypothesis and the carbon-nutrient hypothesis (Bryant et al. 1983; but see also Hamilton et al. 2001 for critics on this hypothesis) predict that $\mathrm{N}$ fertilization decreases concentrations of phenolics in plants. This prediction has been supported by several works (e.g., Gebauer et al. 1997; Hale et al. 2005; Tomova et al. 2005). Some studies have been designed to test the links among fertility, phenolics, and resistance to pathogens in trees. Blodgett et al. (2005) found that susceptibility of red pine 
(Pinus resinosa) to Sphaeropsis sapinea increased, and lignin (locally and distally) and total soluble phenolics (distally) decreased following fertilization. In Austrian pine, fertility was found to affect phenolic glycosides that were identified as important factors in expression of SIR (Wallis et al. 2008). Hakulinen (1998) found no increase in leaf rust frequency in $\mathrm{N}$-fertilized willows, although fertilization tended to reduce the concentrations of phenolics in leaves. Similarly, no effect of fertilization was found on either phloem phenolic composition of Scots pine and Norway spruce (Kytö et al. 1998) or on Norway spruce resistance to Ceratocystis polonica (Kytö et al. 1996). Since individual secondary compounds may vary considerably in their responses to $\mathrm{N}$ fertilization (e.g., Viiri et al. 2001) and the anti-microbial activity also varies considerably even among chemically closely related phenolics (Weidenbörner and Jha 1994), it is likely that the consequences of $\mathrm{N}$-induced changes in phenolic profiles to the resistance to pathogens in trees vary widely. The effect of $\mathrm{N}$ addition on tree resistance through altered phenolic metabolism may remain negligible in forests with high inherent variation among trees and soil nutrient status. However, the tendency of $\mathrm{N}$ to reduce concentrations of defensive phenolics in trees may be amplified by intensive silviculture methods, such as repeated fertilization of young Norway spruce stands (Bergh et al. 2005), especially if the stand is genetically homogenous.

An increased $\mathrm{CO}_{2}$ level in the atmosphere is often expected to result in enhanced synthesis and accumulation of carbon-based secondary metabolites in plants (Gebauer et al. 1997; Peñuelas and Estiarte 1998). However, the responses of phenolic metabolism to $\mathrm{CO}_{2}$ vary considerably among tree species, individual phenolic metabolites, and experimental conditions (Heyworth et al. 1998; Sallas et al. 2001; Percy et al. 2002). Meta-analysis is a tool that has been increasingly used to uncover general trends behind conflicting results from empirical studies (Leimu and Koricheva 2004). For instance, Stiling and Cornelissen (2007) and Veteli et al. (2007) used meta-analysis to study $\mathrm{CO}_{2-}$ mediated changes on phenolics in plants. Their analyses showed that the concentrations of phenolics indeed increased due to $\mathrm{CO}_{2}$ enrichment. In contrast, the meta-analysis of Zvereva and Kozlov (2006) showed that concentrations of phenolics tended to decrease at elevated temperature, which is often associated with $\mathrm{CO}_{2}$ enrichment. However, while the effects of $\mathrm{CO}_{2}$ enrichment or warming on defensive phenolics and herbivores of trees have been extensively studied, alterations in resistance to pathogens have rarely been systematically tested. Hence, it is difficult to predict the consequences of altered phenolic status in trees under warming or $\mathrm{CO}_{2}$ enrichment on pathogens. Because of the complex physiological feedbacks in plants and because of the direct effects of $\mathrm{CO}_{2}$ and warming on the pathogens it may not be realistic to expect general patterns.

Stratospheric ozone $\left(\mathrm{O}_{3}\right)$ protects living organisms against harmful UV radiation, but increased tropospheric $\mathrm{O}_{3}$ can be phytotoxic. $\mathrm{O}_{3}$ has the potential to react with diverse cell constituents to yield active oxygen species, which can be toxic for plant cells or may activate defensive responses in plants, such as programmed cell death (Sandermann 2000 and references therein; Baier et al. 2005). Effects of elevated $\mathrm{O}_{3}$, alone and in combination with elevated $\mathrm{CO}_{2}$, on tree leaf chemistry have been recently reviewed by Valkama et al. (2007) using a meta-analysis approach. They found that concentrations of phenolics were increased by $16 \%$ in response to $\mathrm{O}_{3}$ levels that were 1.5 times higher than the ambient level. Despite the observed increase in phenolic compounds, exposure to $\mathrm{O}_{3}$ has been found to alter the susceptibility of plants to pathogens in different ways (Beare et al. 1999; Percy et al. 2002). In Scots pine seedlings, for example, Chiron et al. (2000) found that induction of stilbene synthase and PS methyltransferase genes following wounding or L. wingfieldii inoculation, in conjunction with $\mathrm{O}_{3}$ stress, depended on the ozone concentration. Pretreatment with $\mathrm{O}_{3}$ at $0.15 \mu \mathrm{L} \cdot \mathrm{L}^{-1}$ decreased the transient induction of these genes following wounding or fungal inoculation, whereas $0.3 \mu \mathrm{L} \cdot \mathrm{L}^{-1}$ prolonged the induction over 2 weeks. This suggests that the physiological responses to $\mathrm{O}_{3}$ may have dynamic thresholds, thereby complicating the prediction of $\mathrm{O}_{3}$ effects on plant metabolism. In young Sitka spruce (Picea sitchensis) and Norway spruce trees, there is no evidence of a link between the effects of $\mathrm{O}_{3}$ exposure on stilbene glucoside concentrations and resistance to Heterobasidion annosum (Pearce and McLeod 1995; Pearce $1996 b)$. This suggests that stilbene glucosides may not determine the resistance to this fungus in spruce (see also Toscano Underwood and Pearce 1992). Interestingly, in a semi-axenic study on the Scots pine - Heterobasidion annosum system, Bonello et al. (1993) found that $\mathrm{O}_{3}$ induced variable effects on the concentrations of soluble and wallbound phenolics, but these effects were pathogen dependent, i.e., $\mathrm{O}_{3}$ alone did not cause changes in their concentrations. Thus, the consequences of $\mathrm{O}_{3}$ enrichment on the resistance of trees to pathogens may not be readily explained by direct $\mathrm{O}_{3}$-induced effects on phenolics.

As a consequence of human activities (including the release of $\mathrm{O}_{3}$-depleting halogens and production of greenhouse gases) large parts of the stratospheric $\mathrm{O}_{3}$ pool have been destroyed, leading to increased penetration of harmful UV-B radiation (wavelength range $280-320 \mathrm{~nm}$ ) to the earth. Induced production of UV-screening phenolics (in particular, hydroxycinnamic acids and flavonoids) in response to UV$\mathrm{B}$ radiation may protect the cells by reducing the penetration of UV-B radiation to the mesophyll (Julkunen-Tiitto et al. 2005). Information about the effect of UV-B radiation on phenolics seems to be variable. In some experiments, UV-B enhancement has had significant effects on the phenolic metabolism of forest trees (Lavola et al. 1998; Fischbach et al. 1999), whereas in others no significant effects have been found (Turtola et al. 2006). In general, little is still known about the possible phenolic-mediated effects of UV radiation on the resistance of forest trees to pathogens. Tegelberg et al. (2001) reported that long-term UV treatment (over three growth seasons) of silver birch (Betula pendula) seedlings resulted in compound-specific alterations within the phenolic pool mainly during the first 2 years, while the constitutive concentrations were unaffected during the third year. The cited authors did not find any UV-B effects on the number of birch leaf rust pustules per leaf area, suggesting that the observed UV-B-induced alterations in phenolics did not have consequences for the leaf rust resistance of birches.

The current concern about the consequences of global climate change has stimulated numerous experimental studies 
in which the effects of environmental variables on tree phenolics have been investigated (Peñuelas and Estiarte 1998; Percy et al. 2002; Valkama et al. 2007 and references therein). Meta-analysis has been useful in exploring the effects of environment of phenolics, and the great responsiveness of tree phenolic metabolism to environmental changes is currently well demonstrated. However, only a few studies have systematically tested the consequences of environmentally induced phenolic responses on the resistance of trees to pathogens (but see Blodgett et al. 2007). In addition, temporally limited experiments rarely allow us to study the cumulative effects of environmental variations or to address the relevance of the dynamics of pathogen populations. Therefore, we still know relatively little about how environmentally induced alterations in phenolics may affect tree resistance to pathogens.

\section{Fungal strategies and cell oxidative processes - keys to understanding the role of phenolics in defense}

The examples from recent literature cited above illustrate the fact that the effects of fertilizers, air pollutants, and UV light on the phenolic-based defenses of forest trees against pathogens vary considerably depending on the plant genotype and compound(s) in question. The role of phenolics in plant resistance may remain unclear partly because of their multiple functions in plants, as has been described for a particular group of phenolics, the flavonoids (Treutter 2006). The detection of definite trends is further complicated by the fact that the impact of the plant phenolic status may vary considerably among pathogens with different life strategies. In addition, the mode of parasitism (infection biology) of the fungus is critical in determining its interaction with plant phenolics. For instance, the mycelium of rusts is generally confined to the intracellular spaces and releases low levels of enzymes that degrade plant cell walls (Larous and Lösel 1993). This mode of infection diminishes the exposure of fungal cells to toxic concentrations of vacuole-located phenolics, such as low molecular weight glycosides. Thus, even in the studies with most advanced analysis techniques, a thorough understanding of the spatial and temporal dynamics of the particular tree-pathogen interaction in question is necessary.

One way to understand the multiple functions of phenolics in plants under combined abiotic and biotic stresses is to look at the basic cellular mechanisms that involve phenolics. Several studies have indicated that the role of phenolics in resistance of trees is linked to their involvement in the oxidative processes in cells (e.g., Treutter 2006; Ruuhola et al. 2008). In fact, the effects of abiotic and biotic factors on phenolics and on plant resistance may be mediated by the oxidative pressure at the cellular level. Close and McArthur (2002) postulate that the type, distribution, and abundance of phenolics may be explained as a response by plants to prevent or minimize oxidative pressure produced from excess light energy and to quench reactive chemical species. This view challenges the traditionally accepted view that herbivores are the crucial selective pressure for phenolics.

The mechanisms by which the phenolics and oxidative metabolism could interact in diseased trees have not been studied in detail. In many cases, phenolics are suggested to act as antioxidants and thereby contribute to protection against damage. Several phenolics can act as antioxidants by donating electrons to guaiacol-type (class III) peroxidases that have been implicated, for example, in lignification and pathogen defense (Perez et al. 2002). The phenoxyl radicals that are formed can then be reduced by the ubiquitous cell antioxidant, ascorbate (Sakihama et al. 2002). However, phenoxyl radicals may also exhibit pro-oxidant activity under conditions that prolong the radical lifetime (e.g., microbial attack) and catalyze cellular DNA degradation in the presence of transition metals, such as iron (Li et al. 2000; Sakihama et al. 2002; Bhat et al. 2007). In plants, iron is a ubiquitous redox-active element, and its redistribution between apoplast and cytosol has been suggested to mediate expression of defense responses in plants (Liu et al. 2007). Although the chemical interactions between phenolics and iron are well documented, we are not aware of studies on the interaction between phenolics and iron homeostasis in forest trees attacked by pathogens. In future, studies addressing this particular mechanism should help us to define the precise role of phenolics in tree resistance.

\section{Practical applications}

Practical, large-scale forest protection methods, based on the tree's own phenolic substances, still seem to be under development. In principle, such methods could be based on (1) traditional resistance breeding for phenolic characters, (2) environmental regulation (e.g., fertilization treatments), (3) genetic modification of phenolic metabolism, or (4) enhancement of phenolic metabolism in trees by treatments with biological or chemical inducers. Currently, traditional breeding does not appear to be an effective means of increasing the phenolic-based resistance in trees, since it is laborious and the breeding cycle for most trees is counted in decades. Although it is important to consider the modifying effects of fertilizer treatments (or other environmental factors) on the phenolics and resistance of trees to pathogens, these effects appear too unpredictable to provide reliable methods for regulating phenolic concentrations in trees.

In recent years there has been great progress in techniques for genetical engineering of trees. Poplar, in particular, with its small and well-characterized genome, has become the model system for tree molecular biology studies (Boerjan 2005; Jansson and Douglas 2007). However, improving the resistance of forest trees to pathogens by genetically altering their phenolic metabolism is likely to be difficult. Seppänen et al. (2004) transferred a pinosylvin-synthase-encoding gene from Scots pine into aspen and two hybrid aspen (Populus tremula $\times$ Populus tremuloides) clones. The transgenic lines expressed the transgene and showed stilbene synthase enzyme activity in vitro, but stilbenes or their glycosides could not be detected in the same lines. While the transgenic aspen line showed increased resistance to decay (caused by Phellinus tremulae), the two hybrid aspen lines showed increased susceptibility. This example not only illustrates the complex regulation of phenolic metabolism in trees, but also underlines that the antifungal activity may not be the main functional character of phenolics in resistance (see above). In the context of genetic engineering of trees, it is important to consider that modifications of primary metabolism also may bring about unintentional changes in phenolic metabolism, and that these changes may affect the resistance 
of trees to pathogens. For instance, Hjältén et al. (2007b) found that overexpression of the enzyme sucrose phosphate synthase induced unintentional changes in concentrations of defensive phenolics. Alterations in host resistance to pathogens could also be expected in trees with a down-regulated lignin pathway (Hu et al. 1999; Peña and Séguin 2001). In general, the use of genetically modified trees still faces technical and ethical problems that need to be overcome before large-scale applications are possible (Herrera 2005).

In the light of the current knowledge, it seems that the most potential and sustainable method for exploiting the phenolic-based defense of forest trees is through activation of phenolic metabolism as a part of the systemic induced response, using external agents as inducers (e.g., salicylic acid, jasmonates, or microbes) (Bonello et al. 2001; Krokene et al. 2001; Percival 2001; Franceschi et al. 2002; Bonello and Blodgett 2003; Hudgins et al. 2004; Zeneli et al. 2006; Eyles et al. 2007; Wallis et al. 2008). However, more research is needed before we can fully use the potential of phenolics in induced resistance at individual-tree, stand, and landscape levels. Crucial topics that need to be studied further include spatial and temporal aspects of induction, the spectrum of effectiveness of induction, and linkages to multitrophic interactions (cf. Eyles et al. 2007), as well as its environmental regulation.

\section{Concluding remarks}

This review summarizes some of the recent literature dealing with the role of phenolics in the resistance of forest trees to pathogens. Although the selection of literature is inevitably restricted, leaving out several distinguished papers and interesting issues, it should be sufficient to highlight the central issues considered, to illustrate the research areas that have been emphasized, and to outline current knowledge on the subject. The general picture arising from the literature is that the relationship between tree phenolics and resistance to pathogens is ambiguous. The varying results may partly be due to the practical problems related to studying tree-pathogen interactions that generally show great spatial and temporal heterogeneity. Furthermore, the expression of other types of defenses, such as terpenes or defensive proteins, in trees complicates the interpretation of results from targeted analyses of phenolics. In the future, some of these problems may be at least partly overcome by creatively combining advanced microscopy and metabolic fingerprinting. We may also be able to increasingly use genetically modified tree lines (e.g., poplars) in the studies. All these possibilities should help us better understand the regulation of phenolic metabolism in attacked and diseased trees. Elucidating the possible role of phenolics in the systemic induced response of trees (e.g., Bonello et al. 2006) remains an exciting challenge for future studies, especially since it may lead to practical applications such as "vaccination" of trees against natural enemies (Christiansen and Krokene 1999; Percival 2001; Wallis et al. 2008).

Some researchers have advocated that we should change the way we think about the role of phenolics in plant defense against herbivores (Close and McArthur 2002; Ruuhola et al. 2008). In parallel, we may also have to reevaluate the traditionally expected functions of phenolics in resistance of trees to pathogens. In tree-pathogen interactions, phenolics may not only act as toxins (e.g., as phytoalexins) that help to confine the infections, but they may also provide indirect protection against the damage caused by pathogens. This protection could be due to the activity of phenolics as antioxidants or as modulators of the activity of other phytochemicals (e.g., polyamines, see Martin-Tanguy 1997). Such functions may be more closely integrated with tolerance (the capacity of the plants to adjust their physiology to buffer the adverse effects of stress factors) (Haukioja and Koricheva 2000) than with direct defense mechanisms. In natural habitats, tolerance to nonlethal degrees of diseases, rather than activation and maintenance of specific defensive mechanisms, may be energetically preferable and promote the ecological success of long-lived forest trees (cf. Bonello et al. 2006). We recommend that future studies addressing the role of phenolics in tree resistance to pathogens give increasing attention to (1) the involvement of phenolics in oxidative metabolism, (2) the possible links between phenolics and primary metabolism (tolerance to damage), and (3) the spatial and temporal synchrony of phenolics with the infection biology of invading pathogens.

\section{Acknowledgements}

We are grateful for the critical comments of Erik Christiansen, Rolf Gref, Paal Krokene, Julia Koricheva, Torgny Näsholm, Olli-Pekka Tikkanen, and Jesper Witzell during the writing process, and for the constructive comments of three anonymous referees. Juan A. Martín was supported by a postdoctoral grant from Ministero de Educación y Ciencia (Spain).

\section{References}

Asiegbu, F.O. 2000. Effects of carbohydrates, ethanol and selected cell wall phenolics on in vitro growth of necrotrophic fungi Heterobasidion annosum and Fusarium avenaceum. J. Basic Microbiol. 40: 139-148. doi:10.1002/1521-4028(200007) 40:3<139::AID-JOBM139>3.0.CO;2-1. PMID:10957955.

Bahnweg, G., Schubert, R., Kehr, R.D., Müller-Starck, G., Heller, W., Langebartels, C., and Sanderman, H., Jr. 2000. Controlled inoculation of Norway spruce with Sirococcus conigenus: PCRbased quantification of the pathogen in host tissue and infectionrelated increase of phenolic metabolites. Trees (Berlin), 14: 435-441. doi:10.1007/s004680000058.

Baier, M., Kandlbinder, A., Golldack, D., and Dietz, K.J. 2005. Oxidative stress and ozone: perception, signalling and response. Plant Cell Environ. 28: 1012-1020. doi:10.1111/j.1365-3040. 2005.01326.x.

Beare, J.A., Archer, S.A., and Bell, J.N.B. 1999. Marssonina leafspot disease of poplar under elevated ozone: pre-fumigated host and in vitro studies. Environ. Pollut. 105: 409-417. doi:10.1016/ S0269-7491(99)00034-2.

Bergh, J., Linder, S., and Bergström, J. 2005. Potential production of Norway spruce in Sweden. For. Ecol. Manage. 204: 1-10. doi:10.1016/j.foreco.2004.07.075.

Bergström, B., Gustafsson, G., Gref, R., and Ericsson, A. 1999. Seasonal changes of pinosylvin distribution in the sapwood/ heartwood boundary of Pinus sylvestris. Trees (Berlin), 14: 6571. doi:10.1007/PL00009754.

Bernards, M.A. 2002. Demystifying suberin. Can. J. Bot. 80: 227240. doi:10.1139/b02-017.

Bhat, S.H., Azmi, A.S., and Hadi, S.M. 2007. Prooxidant DNA breakage induced by caffeic acid in human peripheral lympho- 
cytes: involvement of endogenous copper and a putative mechanism for anticancer properties. Toxicol. Appl. Pharmacol. 218: 249-255. doi:10.1016/j.taap.2006.11.022. PMID:17208261.

Blodgett, J.T. , and Stanosz, G.R. 1998. Monoterpene and phenolic compound concentrations in water-stressed red pine inoculated with Sphaeropsis sapinea. Phytopathology, 88: 245-251. doi:10. 1094/PHYTO.1998.88.3.245.

Blodgett, J.T., Herms, D.A., and Bonello, P. 2005. Effects of fertilization on red pine defense chemistry and resistance to Sphaeropsis sapinea. For. Ecol. Manage. 208: 373-382. doi:10.1016/j. foreco.2005.01.014.

Blodgett, J.T., Eyles, A., and Bonello, P. 2007. Organ-dependent induction of systemic resistance and systemic susceptibility in Pinus nigra inoculated with Sphaeropsis sapinea and Diplodia scrobiculata. Tree Physiol. 27: 511-517. PMID:17241993.

Boerjan, W. 2005. Biotechnology and the domestication of forest trees. Curr. Opin. Biotechnol. 16: 159-166. doi:10.1016/j. copbio.2005.03.003. PMID:15831381.

Bois, E., and Lieutier, F. 1997. Phenolic response of Scots pine clones to inoculation with Leptographium wingfieldii, a fungus associated with Tomicus piniperda. Plant Physiol. Biochem. 35: 819-825.

Bonello, P., and Blodgett, J.T. 2003. Pinus nigra - Sphaeropsis sapinea as a model pathosystem to investigate local and systemic effects of fungal infection of pines. Physiol. Mol. Plant Pathol. 63: 249-261. doi:10.1016/j.pmpp.2004.02.002.

Bonello, P., Heller, W., and Sanderman, H., Jr. 1993. Ozone effects on root-disease susceptibility and defense responses in mycorrhizal and non.mycorrhizal seedlings of Scots pine (Pinus sylvestris L.). New Phytol. 124: 653-663. doi:10.1111/j.1469-8137.1993. tb03855.x.

Bonello, P., Gordon, T.R., and Storer, A.J. 2001. Systemic induced resistance in Monterey pine. For. Pathol. 31: 99-106. doi:10. 1046/j.1439-0329.2001.00230.x.

Bonello, P., Storer, A.J., Gordon, T.R., Wood, D.L., and Heller, W. 2003. Systemic effects of Heterobasidion annosum on ferulic acid glucoside and lignin of pre-symptomatic ponderosa pine phloem, and potential effects on bark beetle-associated fungi. J. Chem. Ecol. 29: 1167-1182. doi:10.1023/A:1023833707382. PMID:12857029.

Bonello, P., Gordon, T.R., Herms, D.A., Wood, D.L., and Erbilgin, N. 2006. Nature and ecological implications of pathogen-induced systemic resistance in conifers: a novel hypothesis. Physiol. Mol. Plant Pathol. 68: 95-104. doi:10.1016/j.pmpp.2006. 12.002 .

Børja, I., Sharma, P., Krekling, T., and Lönneborg, A. 1995. Cytopathological response in roots of Picea abies seedlings infected with Pythium dimorphum. Phytopathology, 85: 495-501. doi:10. 1094/Phyto-85-495.

Brignolas, F., Lieutier, F., Sauvard, D., Christiansen, E., and Berryman, A.A. 1998. Phenolic predictors for Norway spruce resistance to the bark beetle Ips typographus (Coleoptera: Scolytidae) and an associated fungus, Ceratocystis polonica. Can. J. For. Res. 28: 720-728. doi:10.1139/cjfr-28-5-720.

Bryant, J.P., Chapin, F.S., and Klein, D.R. 1983. Carbon/nutrient balance of boreal plants in relation to vertebrate herbivory. Oikos, 40: 357-368. doi:10.2307/3544308.

Bucciarelli, B., Ostry, M.E., Fulcher, R.G., Andersson, N.A., and Vance, C.P. 1999. Histochemical and microspectrophotometric analyses of early wound responses of resistant and susceptible Populus tremuloides inoculated with Entoleuca mammata (Hypoxylon mammatum). Can. J. Bot. 77: 548-555. doi:10.1139/ cjb-77-4-548.

Chiron, H., Drouet, A., Lieutier, F., Payer, H.D., Ernst, D., and Sanderman, H., Jr. 2000. Gene induction of stilbene biosynthesis in Scots pine in response to ozone treatment, wounding and fungal infection. Plant Physiol. 124: 865-872. doi:10.1104/pp.124. 2.865. PMID:11027734.

Christiansen, E., and Krokene, P. 1999. Can Norway spruce trees be "vaccinated" against attack by Ips typographus? Agric. For. Entomol. 1: 185-187. doi:10.1046/j.1461-9563.1999.00024.x.

Close, D.C., and McArthur, C. 2002. Rethinking the role of many plant phenolics — protection from photodamage not herbivores? Oikos, 99: 166-172. doi:10.1034/j.1600-0706.2002.990117.x.

Crane, P.E., Blenis, P.V., and Hiratsuka, Y. 1994. Black stem galls on aspen and their relationship to decay by Phellinus tremulae. Can. J. For. Res. 24: 2240-2243. doi:10.1139/x94-287.

Cvikrová, M., Malá, J., Hrubcová, M., and Eder, J. 2006. Soluble and cell wall-bound phenolics and lignin in Ascocalyx abietina infected Norway spruces. Plant Sci. 170: 563-570. doi:10.1016/ j.plantsci.2005.10.011.

Elamo, P., Saloniemi, I., Helander, M.L., and Neuvonen, S. 2000. Genetic and environmental variation in rust frequency on mature mountain birch trees. Scand. J. For. Res. 15: 510-522. doi:10. 1080/028275800750173438.

Erbilgin, N., Krokene, P., Christiansen, E., Zeneli, G., and Gershenzon, J. 2006. Exogenous application of methyl jasmonate elicits defenses in Norway spruce (Picea abies) and reduces host colonization by the bark beetle Ips typographus. Oecologia (Berlin), 148: 426-436. doi:10.1007/s00442-006-0394-3.

Evensen, P.C., Solheim, H., Hoiland, K., and Stenersen, J. 2000. Induced resistance of Norway spruce, variation of phenolic compounds and their effects on fungal pathogens. For. Pathol. 30: 97-108. doi:10.1046/j.1439-0329.2000.00189.x.

Eyles, A., Chorbadjian, R., Wallis, C., Hansen, R., Cipollini, D., Herms, D., and Bonello, P. 2007. Cross-effects of systemic induced resistance between an insect and a fungal pathogen in Austrian pine over a fertility gradient. Oecologia (Berlin), 153: 365-374. doi:10.1007/s00442-007-0741-z.

Fiehn, O. 2002. Metabolomics — the link between genotype and phenotype. Plant Mol. Biol. 48: 155-171. doi:10.1023/ A:1013713905833. PMID:11860207.

Fischbach, R.J., Kossmann, B., Panten, H., Steinbrecher, R., Heller, W.S., Eidlitz, H.K., Sandermann, H., Hertkorn, N., and Schnitzler, J.-P. 1999. Seasonal accumulation of ultraviolet-B screening pigments in needles of Norway spruce (Picea abies (L.) Karst.). Plant Cell Environ. 22: 27-37. doi:10.1046/j.1365-3040. 1999.00390.x.

Franceschi, V.R., Krekling, T., Berryman, A.A., and Christiansen, E. 1998. Specialized phloem parenchyma cells in Norway spruce (Pinaceae) bark are an important site of defense reactions. Am. J. Bot. 85: 601-615. doi:10.2307/2446529.

Franceschi, V.R., Berryman, A.A., and Christiansen, E. 2000. The structure and development of polyphenolic parenchyma cells in Norway spruce (Picea abies) bark. Flora, 195: 354-369.

Franceschi, V.R., Krekling, T., and Christiansen, E. 2002. Application of methyl jasmonate on Picea abies (Pinaceae) stems induces defense-related responses in phloem and xylem. Am. J. Bot. 89: 578-586. doi:10.3732/ajb.89.4.578.

Franceschi, V.R., Krokene, P., Christiansen, E., and Krekling, T. 2005. Anatomical and chemical defenses of conifer bark against bark beetles and other pests. New Phytol. 167: 353-376. doi:10. 1111/j.1469-8137.2005.01436.x. PMID:15998390.

Freiwald, V. 2008. Does elevated ozone predispose northern deciduous tree species to abiotic and biotic stresses? Doctoral dissertation, Kuopio University Publications C, Natural and Environmental Sciences 227, Kuopio, Finland.

Gebauer, R.L.E., Strain, B.R., and Reynolds, J.F. 1997. The effect of elevated $\mathrm{CO}_{2}$ and $\mathrm{N}$ availability on tissue concentrations and 
whole plant pools of carbon-based secondary compounds in loblolly pine (Pinus taeda). Oecologia (Berlin), 113: 29-36. doi:10.1007/s004420050350.

Hakulinen, J. 1998. Nitrogen-induced reduction in leaf phenolic level is not accompanied by increased rust frequency in a compatible willow (Salix myrsinifolia)-Melampsora rust interaction. Physiol. Plant. 102: 101-110. doi:10.1034/j.1399-3054.1998. 1020114.x.

Hakulinen, J., and Julkunen-Tiitto, R. 2000. Variation in leaf phenolics of field-cultivated willow (Salix sp.) clones in relation to occurrence of Melampsora rust. For. Pathol. 30: 29-41. doi:10. 1046/j.1439-0329.2000.00184.x.

Hakulinen, J., Sorjonen, S., and Julkunen-Tiitto, R. 1999. Leaf phenolics of willow clones differing in resistance to Melampsora rust. Physiol. Plant. 105: 662-669. doi:10.1034/j.1399-3054. 1999.105410.x.

Hale, B.K., Herms, D.A., Hansen, R.C., Clausen, T.P., and Arnold, D. 2005. Effects of drought stress and nutrient availability on dry matter allocation, phenolic glycosides, and rapid induced resistance of poplar to two lymantriid defoliators. J. Chem. Ecol. 31: 2601-2620. doi:10.1007/s10886-005-7616-8. PMID:16273431.

Hamilton, J.G., Zangerl, A.R., De Lucia, E.H., and Berenbaum, M.R. 2001. The carbon-nutrient balance hypothesis: its rise and fall. Ecol. Lett. 4: 86-95. doi:10.1046/j.1461-0248.2001.00192.x.

Hammerschmidt, R. 2003. Defense responses: in the orchard and the forest. Physiol. Mol. Plant Pathol. 63: 235-236. doi:10. 1016/j.pmpp.2004.05.001.

Hammerschmidt, R. 2005. Phenols and plant-pathogen interactions: the saga continues. Physiol. Mol. Plant Pathol. 66: 77-78. doi:10.1016/j.pmpp.2005.08.001.

Haukioja, E., and Koricheva, J. 2000. Tolerance to herbivory in woody vs. herbaceous plants. Evol. Ecol. 14: 551-562. doi:10. 1023/A:1011091606022.

Haviola, S., Saloniemi, I., Ossipov, V., and Haukioja, E. 2006. Additive genetic variation of secondary and primary metabolites in mountain birch. Oikos, 112: 382-391. doi:10.1111/j.0030-1299. 2006.14361.x.

Herrera, S. 2005. Struggling to see the forest through the trees. Nat. Biotechnol. 23: 165-167. doi:10.1038/nbt0205-165. PMID:15696138.

Heyworth, C.J., Iason, G.R., Temperton, V., Jarvis, P.G., and Duncan, A.J. 1998. The effect of elevated $\mathrm{CO}_{2}$ concentration and nutrient supply on carbon-based secondary metabolites in Pinus sylvestris L. Oecologia (Berlin), 115: 344-350. doi:10.1007/ s004420050526.

Highley, T.L. 1995. Comparative durability of untreated wood in use above ground. Int. Biodeterior. Biodegrad. 35: 409-419. doi:10.1016/0964-8305(95)00063-1.

Hjältén, J., Niemi, L., Wennström, A., Ericson, L., Roininen, H., and Julkunen-Tiitto, R. 2007a. Variable responses of natural enemies to Salix triandra phenotypes with different secondary chemistry. Oikos, 116: 751-758. doi:10.1111/j.0030-1299.2007. 15365.x.

Hjältén, J., Lindau, A., Wennström, A., Blomberg, P., Witzell, J., Hurry, V., and Ericson, L. 2007b. Unintentional changes of defence traits in GM trees can influence plant-herbivore interactions. Basic Appl. Ecol. 8: 434-443. doi:10.1016/j.baae.2006.09.001.

Honkanen, T., Haukioja, E., and Kitunen, V. 1999. Responses of Pinus sylvestris branches to stimulated herbivory are modified by tree sink/source dynamics and by external resources. Funct. Ecol. 13: 126-140. doi:10.1046/j.1365-2435.1999.00296.x.

Hu, W.J., Harding, S.A., Lung, J., Popko, J.L., Ralph, J., Stokke, D.D., Tsai, C.J., and Chiang, V.L. 1999. Repression of lignin biosynthesis promotes cellulose accumulation and growth in transgenic trees. Nat. Biotechnol. 17: 808-812. doi:10.1038/ 11758. PMID:10429249.

Hudgins, J.W., and Franceschi, V.R. 2004. Methyl jasmonate-induced ethylene production is responsible for conifer phloem defense responses and reprogramming of stem cambial zone for traumatic resin duct formation. Plant Physiol. 135: 2134-2149. doi:10.1104/pp.103.037929. PMID:15299142.

Hudgins, J.W., Christiansen, E., and Franceschi, V.R. 2003. Methyl jasmonate induces changes mimicking anatomical and chemical defenses in diverse members of the Pinaceae. Tree Physiol. 23: 361-371. PMID:12642238.

Hudgins, J.W., Christiansen, E., and Franceschi, V. 2004. Induction of anatomically based defense responses in stems of diverse conifers by methyl jasmonate: a phylogenetic perspective. Tree Physiol. 24: 251-264. PMID:14704135.

Hutzler, P., Fischbach, R., Heller, W., Jungblut, T., Reuber, S., Schmitz, R., Veit, M., Weissenböck, G., and Schnitzler, J.P. 1998. Tissue localization of phenolic compounds in plants by confocal laser scanning microscopy. J. Exp. Bot. 49: 953-965. doi:10.1093/jexbot/49.323.953.

Jansson, S., and Douglas, C.J. 2007. Populus: a model system for plant biology. Annu. Rev. Plant Biol. 58: 435-458 . doi:10. 1146/annurev.arplant.58.032806.103956. PMID:17280524.

Johansson, S.M., Lundgren, L.N., and Asiegbu, F.O. 2004. Initial reactions in sapwood of Norway spruce and Scots pine after wounding and infection by Heterobasidion parviporum and $H$. annosum. For. Pathol. 34: 197-210. doi:10.1111/j.1439-0329. 2004.00358.x

Johnson, J.D., and Kim, Y. 2005. The role of leaf chemistry in Melampsora medusae infection of hybrid poplar: effects of leaf development and fungicide treatment. Can. J. For. Res. 35: 763 771. doi:10.1139/x05-009.

Julkunen-Tiitto, R., Häggman, H., Aphalo, P.J., Lavola, A., Tegelberg, R., and Veteli, T. 2005. Growth and defense in deciduous trees and shrubs under UV-B. Environ. Pollut. 137: 404-414. doi:10.1016/j.envpol.2005.01.050. PMID:16005754.

Krekling, T., Franceschi, V.R., Krokene, P., and Solheim, H. 2004. Differential anatomical responses of Norway spruce stem tissues to sterile and fungus infected inoculations. Trees (Berlin), 18: 19. doi:10.1007/s00468-003-0266-y.

Krokene, P., Christiansen, E., Solheim, H., Berryman, A.A., and Franceschi, V.R. 1999. Induced resistance to pathogenic fungi in Norway spruce. Plant Physiol. 121: 565-570. doi:10.1104/pp. 121.2.565. PMID:10517848.

Krokene, P., Solheim, H., and Långström, B. 2000. Fungal infection and mechanical wounding induce disease resistance in Scots pine. Eur. J. Plant Pathol. 106: 537-541. doi:10.1023/ A: 1008776002248 .

Krokene, P., Solheim, H., and Christiansen, E. 2001. Induction of disease resistance in Norway spruce (Picea abies) by necrotizing fungi. Plant Pathol. 50: 230-233. doi:10.1046/j.1365-3059.2001. 00559.x.

Kruger, B.M., and Manion, P.D. 1994. Antifungal compounds in aspen: effect of water stress. Can. J. Bot. 72: 454-460. doi:10. 1139/b94-060.

Kytö, M., Niemelä, P., and Annila, E. 1996. Vitality and bark beetle resistance of fertilized Norway spruce. For. Ecol. Manage. 84: 149-157. doi:10.1016/0378-1127(96)03731-0.

Kytö, M., Niemelä, P., and Annila, E. 1998. Effects of vitality fertilization on the resin flow and vigour of Scots pine in Finland. For. Ecol. Manage. 102: 121-130. doi:10.1016/S0378-1127(97) 00150-3.

Laitinen, M.L., Julkunen-Tiitto, R., Tahvanainen, J., Heinonen, J., and Rousi, M. 2005. Variation in Birch (Betula pendula) shoot 
secondary chemistry due to genotype, environment, and ontogeny. J. Chem. Ecol. 31: 697-717. doi:10.1007/s10886-0053539-7. PMID: 16124246.

Larous, L., and Lösel, D.M. 1993. Strategies of pathogenicity in monokaryotic and dikaryotic phases of rust fungi, with special reference to vascular infection. Mycol. Res. 97: 415-420.

Lavola, A., Julkunen-Tiitto, R., Roininen, H., and Aphalo, P. 1998. Host-plant preference of an insect herbivore mediated by UV-B and $\mathrm{CO} 2$ in relation to plant secondary metabolites. Biochem. Syst. Ecol. 26: 1-12. doi:10.1016/S0305-1978(97)00104-X.

Leimu, R., and Koricheva, J. 2004. Cumulative meta-analysis: a new tool for detection of temporal trends and publication bias in ecology. Proc. R. Soc. Lond. B Biol. Sci. 271: 1961-1966. doi:10.1098/rspb.2004.2828.

Li, A.S., Bandy, B., Tsang, S.S., and Davison, A.J. 2000. DNAbreaking versus DNA-protecting activity of four phenolic compounds in vitro. Free Radic. Res. 33: 551-566. doi:10.1080/ 10715760000301091. PMID:11200088.

Lieutier, F., Sauvard, D., Brignolas, F., Picron, V., Yart, A., Bastien, C., and Jay-Allemand, C. 1996. Changes in phenolics metabolites of Scots pine induced by Ophiostoma brunneo-ciliatum, a bark beetle associated fungus. For. Pathol. 26: 145-216. doi:10.1111/j.1439-0329.1996.tb00719.x.

Lieutier, F., Brignolas, F., Sauvard, D., Yart, A., Galet, C., Brunet, M., and Van de Sype, H. 2003. Intra- and inter-provenance variability in phloem phenols of Picea abies and relationship to a bark beetle-associated fungus. Tree Physiol. 23: 247-256. PMID:12566260.

Liu, G., Greenshields, D.L., Sammynaiken, R., Hirji, R.N., Selvaraj, G., and Wei, Y. 2007. Targeted alterations in iron homeostasis underlie plant defense responses. J. Cell Sci. 120: 596605. doi:10.1242/jcs.001362. PMID:17244651.

Maher, E.A., Bate, N.J., Ni, W., Elkind, Y., Dixon, R.A., and Lamb, C.J. 1994. Increased disease susceptibility of transgenic tobacco plants with suppressed levels of preformed phenylpropanoid products. Proc. Natl. Acad. Sci. U.S.A. 91: 7802-7806. doi:10.1073/pnas.91.16.7802. PMID:8052663.

Marinova, K., Kleinschmidt, K., Weissenböck, G., and Klein, M. 2007. Flavonoid biosynthesis in barley primary leaves requires the presence of the vacuole and controls the activity of vacuolar flavonoid transport. Plant Physiol. 144: 432-444. doi:10.1104/ pp.106.094748. PMID: 17369433.

Martín, J.A., Solla, A., Coimbra, S., and Gil, L. 2005a. Metabolic distinction of Ulmus minor xylem tissues after incoculation with Ophiostoma novo-ulmi. Phytochemistry, 66: 2458-2467. doi:10. 1016/j.phytochem.2005.08.004. PMID:16176827.

Martín, J.A., Solla, A., Woodward, S., and Gil, L. 2005b. FT-IR spectroscopy as a new method for evaluating host resistance in the Dutch elm disease complex. Tree Physiol. 25: 1331-1338. PMID:16076781.

Martín, J.A., Solla, A., Woodward, S., and Gil, L. 2007. Detection of differential changes in lignin composition of elm xylem tissues inoculated with Ophiostoma novo-ulmi using Fourier transform-infrared spectroscopy. For. Pathol. 37: 187-191. doi:10. 1111/j.1439-0329.2007.00495.x.

Martin-Tanguy, J. 1997. Conjugated polyamines and reproductive development: biochemical, molecular and physiological approaches. Physiol. Plant. 100: 675-688. doi:10.1111/j.13993054.1997.tb03074.x.

Nagy, N.E., Fossdal, C.G., Krokene, P., Krekling, T., Lonneborg, A., and Solheim, H. 2004. Induced responses to pathogen infection in Norway spruce phloem: changes in polyphenolic parenchyma cells, chalcone synthase transcript levels and peroxidase activity. Tree Physiol. 24: 505-515. PMID:14996655.
Ollerstam, O., and Larsson, S. 2003. Salicylic acid mediates resistance in the willow Salix viminalis against gall midge Dasineura marginemtorquens. J. Chem. Ecol. 29: 163-174. doi:10.1023/ A:1021936832258. PMID:12647860.

Osier, T.L., and Lindroth, R.L. 2001. Effects of genotype, nutrient availability, and defoliation on aspen phytochemistry and insect performance. J. Chem. Ecol. 27: 1289-1313. doi:10.1023/ A:1010352307301. PMID:11504029.

Pausler, M., Ayer, W.A., and Hiratsuka, Y. 1995. Benzoic acid, salicylic acid, and the role of black galls on aspen in protection against decay. Can. J. For. Res. 25: 1479-1483. doi:10.1139/ x95-160.

Pearce, R.B. 1996a. Antimicrobial defences in the wood of living trees. New Phytol. 132: 203-233. doi:10.1111/j.1469-8137. 1996.tb01842.x.

Pearce, R.B. 1996b. Effects of exposure to high ozone concentrations on stilbenes in Sitka spruce (Picea sitchensis (Bong.) Carr.) bark and on its lignification response to infection with Heterobasidion annosum (Fr.) Bref. Physiol. Mol. Plant. Pathol. 48: 117-129. doi:10.1006/pmpp.1996.0011.

Pearce, R.B., and McLeod, A.R. 1995. Effects of suphur dioxide and ozone on stilbenes and disease resistance in spruce trees from the Liphook Forest fumigation project. Plant Cell Environ. 18: 303-307. doi:10.1111/j.1365-3040.1995.tb00365.x.

Peña, L., and Séguin, A. 2001. Recent advances in the genetic transformation of trees. Trends Biotechnol. 19: 500-506. doi:10. 1016/S0167-7799(01)01815-7. PMID:11711193.

Peñuelas, J., and Estiarte, M. 1998. Can elevated $\mathrm{CO}_{2}$ affect secondary metabolism and ecosystem function? Trends Ecol. Evol. 13: 20-24. doi:10.1016/S0169-5347(97)01235-4.

Percival, G.C. 2001. Induction of systemic acquired disease resistance in plants: potential implications for disease management in urban forestry. J. Arboric. 27: 181-192.

Percy, K.E., Awmack, C.S., Lindroth, R.L., Kubiske, M.E., Kopper, B.J., Isebrands, J.G., Pregitzer, K.S., Hendrey, G.R., Dickson, R.E., Zak, D.R., Oksanen, E., Sober, J., Harrington, R., and Karnosky, D.F. 2002. Altered performance of forest pests under atmospheres enriched by $\mathrm{CO}_{2}$ and $\mathrm{O}_{3}$. Nature (London), 420: 403-407. doi:10.1038/nature01028. PMID: 12459738.

Perez, F.J., Villegas, D., and Mejia, N. 2002. Ascorbic acid and flavonoid-peroxidase reaction as a detoxifying system of $\mathrm{H}_{2} \mathrm{O}_{2}$ in grapevine leaves. Phytochemistry, 60: 573-580. doi:10.1016/ S0031-9422(02)00146-2. PMID:12126703.

Riipi, M., Ossipov, V., Lempa, K., Haukioja, E., Koricheva, J., Ossipova, S., and Pihlaja, K. 2002. Seasonal changes in birch leaf chemistry: are there trade-offs between leaf growth and accumulation of phenolics? Oecologia (Berlin), 130: 380-390. doi:10. 1007/s00442-001-0826-z.

Rioux, D., and Ouellette, G.B. 1991. Barrier zone formation in host and nonhost trees inoculated with Ophiostoma ulmi. I. Anatomy and histochemistry. Can. J. Bot. 69: 2055-2073. doi:10.1139/ b91-258.

Ruuhola, T., Yang, S., Ossipov, V., and Haukioja, E. 2008. Foliar oxidases as mediators of the rapidly induced resistance of mountain birch against Epirrita autumnata. Oecologia (Berlin), 154: 725-730. doi:10.1007/s00442-007-0869-x.

Sakihama, Y., Cohen, M.F., Grace, S.C., and Yamasaki, H. 2002. Plant phenolic antioxidant and prooxidant activities: phenolicsinduced oxidative damage mediated by metals in plants. Toxicology, 177: 67-80. doi:10.1016/S0300-483X(02)00196-8. PMID:12126796.

Sallas, L., Kainulainen, P., Utriainen, J., Holopainen, T., and Holopainen, J.K. 2001. The influence of elevated $\mathrm{O}_{3}$ and $\mathrm{CO}_{2}$ concentrations on secondary metabolites of Scots pine (Pinus 
sylvestris L.) seedlings. Glob. Change Biol. 7: 303-311. doi:10. 1046/j.1365-2486.2001.00408.x.

Sallé, A., Monclus, R., Yart, A., and Lieutier, F. 2005. Effect of phenolic compounds on the in vitro growth of two fungi associated with Ips typographus. For. Pathol. 35: 298-304. doi:10. 1111/j.1439-0329.2005.00409.x.

Salminen, J.P., Ossipov, V., Haukioja, E., and Pihlaja, K. 2001. Seasonal variation in the content of hydrolysable tannins in leaves of Betula pubescens. Phytochemistry, 57: 15-22. doi:10. 1016/S0031-9422(00)00502-1. PMID:11336256.

Sandermann, H., Jr. 2000. Ozone/biotic disease interactions: molecular biomarkers as a new experimental tool. Environ. Pollut. 108: 327-332. doi:10.1016/S0269-7491(99)00211-0. PMID:15092927.

Scalbert, A. 1991. Antimicrobial properties of tannins. Phytochemistry, 30: 3875-3883. doi:10.1016/0031-9422(91)83426-L.

Schultz, T.P., and Nicholas, D.D. 2000. Naturally durable heartwood: evidence for a proposed dual defensive function of the extractives. Phytochemistry, 54: 47-52. doi:10.1016/S00319422(99)00622-6. PMID:10846746.

Seppänen, S.K., Syrjälä, L., von Weissenberg, K., Teeri, T.H., Paajanen, L., and Pappinen, A. 2004. Antifungal activity of stilbenes in in vitro bioassays and in transgenic Populus expressing a gene encoding pinosylvin synthase. Plant Cell Rep. 22: 584593. doi:10.1007/s00299-003-0728-0. PMID:14714142.

Srivastava, V., Schinkel, H., Witzell, J., Hertzberg, M., Torp, M., Srivastava, M.K., Karpinska, B., Melzer, M., and Wingsle, G. 2007. Downregulation of high-isoelectric-point extracellular superoxide dismutase mediates alterations in the metabolism of reactive oxygen species and developmental disturbances in hybrid aspen. Plant J. 49: 135-148. doi:10.1111/j.1365-313X. 2006.02943.x. PMID:17233796.

Stamp, N. 2003. Out of the quagmire of plant defense hypotheses. Q. Rev. Biol. 78: 23-55. doi:10.1086/367580. PMID:12661508.

Stiling, P., and Cornelissen, T. 2007. How does elevated carbon dioxide $\left(\mathrm{CO}_{2}\right)$ affect plant-herbivore interactions? A field experiment and meta-analysis of $\mathrm{CO}_{2}$-mediated changes on plant chemistry and herbivore performance. Glob. Change Biol. 13: 1823-1842. doi:10.1111/j.1365-2486.2007.01392.x.

Tegelberg, R., Julkunen-Tiitto, R., and Aphalo, P. 2001. The effects of long-term elevated UV-B on the growth and phenolics of field-cultivated silver birch (Betula pendula). Glob. Change Biol. 7: 839-848. doi:10.1046/j.1354-1013.2001.00453.x.

Tomova, L., Braun, S., and Flückiger, W. 2005. The effect of nitrogen fertilization on fungistatic phenolic compounds in roots of beech (Fagus sylvatica) and Norway spruce (Picea abies). For. Pathol. 35: 262-276. doi:10.1111/j.1439-0329.2005.00406.x.

Toscano Underwood, C.D., and Pearce, R.B. 1992. Stilbene glucoside levels and the resistance of Sitka spruce (Picea sitchensis) tissues to colonization by root- and butt- rotting fungi. Plant Pathol. 41: 722-729. doi:10.1111/j.1365-3059.1992.tb02555.x.

Treutter, D. 2006. Significance of flavonoids in plant resistance: a review. Environ. Chem. Lett. 4: 147-157. doi:10.1007/s10311006-0068-8.

Turtola, S., Sallas, L., Holopainen, J.K., Julkunen-Tiitto, R., and Kainulainen, P. 2006. Long-term exposure to enhanced UV-B radiation has no significant effects on growth or secondary compounds of outdoor-grown Scots pine and Norway spruce seedlings. Environ. Pollut. 144: 166-171. doi:10.1016/j.envpol.2005. 12.025. PMID: 16515828.

Valkama, E., Koricheva, J., Salminen, J.P., Helander, M., Saloniemi, I., Saikkonen, K., and Pihlaja, K. 2005. Leaf surface traits: overlooked determinants of birch resistance to herbivores and foliar micro-fungi? Trees (Berlin), 19: 191-197. doi:10. 1007/s00468-004-0380-5.
Valkama, E., Koricheva, J., and Oksanen, E. 2007. Effects of elevated $\mathrm{O}_{3}$, alone and in combination with elevated $\mathrm{CO} 2$, on tree leaf chemistry and insect herbivore performance: a meta-analysis. Glob. Change Biol. 13: 184-201. doi:10.1111/j.1365-2486. 2006.01284.x.

VanEtten, H., Mansfield, J.W., Bailey, J.A., and Farmer, E.E. 1994. Two classes of plant antibiotics: phytoalexins versus "phytoanticipins". Plant Cell, 6: 1191. doi:10.1105/tpc.6.9.1191. PMID:12244269.

van Wijk, K.J. 2001. Update on plant proteomics. Challenges and prospects of plant proteomics. Plant Physiol. 126: 501-508. doi:10.1104/pp.126.2.501. PMID:11402181.

Venäläinen, M., Harju, A.M., Kainulainen, P., Viitanen, H., and Nikulainen, H. 2003. Variation in decay resistance and its relationship with other wood characteristics in old Scots pines. Ann. For. Sci. 60: 409-417. doi:10.1051/forest:2003033.

Veteli, T.O., Mattson, W.J., Niemelä, P., Julkunen-Tiitto, R., Kellomäki, S., Kuokkanen, K., and Lavola, A. 2007. Do elevated temperature and $\mathrm{CO}_{2}$ generally have counteracting effects on phenolic phytochemistry of boreal trees? J. Chem. Ecol. 33: 287-296. doi:10.1007/s10886-006-9235-4. PMID:17216360.

Viiri, H., Annila, E., Kitunen, V., and Niemelä, P. 2001. Induced responses in stilbenes and terpenes in fertilized Norway spruce after inoculation with blue-stain fungus Ceratocystis polonica. Trees (Berlin), 15: 112-122. doi:10.1007/s004680000082.

von Beyer, U., Tesche, M., Heller, W., and Sanderman, H. 1993. Fungistatische Wirksamkeit phenolische Inhaltsstoffe der Fichte Picea abies (L.) Karst. und Einfluß von $\mathrm{SO}_{2}$. Eur. J. For. Res. 112: 251-256. doi:10.1007/BF02742153.

Wallis, C., Eyles, A., Chorbadjian, R., McSpadden Gardener, B., Hansen, R., Cipollini, D., Herms, D.A., and Bonello, P. 2008. Systemic induction of phloem secondary metabolism and its relationship to resistance to a canker pathogen in Austrian pine. New Phytol. 177: 767-778. doi:10.1111/j.1469-8137.2007. 02307.x. PMID:18069955.

Weidenbörner, M., and Jha, H.C. 1994. Structure-activity relationships among isoflavonoids with regard to their antifungal properties. Mycol. Res. 98: 1376-1378.

Witzell, J., Karlsson, M., Rodriguez-Buey, M., Torp, M., and Wingsle, G. 2005. Transgenic hybrid aspen with altered defensive chemistry - a model system to study the chemical basis of resistance? In Rust diseases of willows and poplars. Edited by M.H. Pei and A.R. McCracken. CABI Publishing, Wallingford, UK. pp. 155-160.

Woodward, S. 1992. Responses of gymnosperm bark tissues to fungal infections. In Defense mechanisms of woody plants against fungi. Edited by R.A. Blanchette and A.R. Biggs. Springer-Verlag, Berlin. pp. 62-75.

Zanne, A.E., Sweeney, K., Sharma, M., and Orians, C.M. 2006. Patterns and consequences of differential vascular sectoriality in 18 temperate tree and shrub species. Funct. Ecol. 20: 200-206. doi:10.1111/j.1365-2435.2006.01101.x.

Zeneli, G., Krokene, P., Christiansen, E., Krekling, T., and Gershenzon, J. 2006. Methyl jasmonate treatment of mature Norway spruce (Picea abies) trees increases the accumulation of terpenoid resin components and protects against infection by Ceratocystis polonica, a bark beetle-associated fungus. Tree Physiol. 26: 977-988. PMID:16651247.

Zvereva, E., and Kozlov, M. 2006. Consequences of simultaneous elevation of carbon dioxide and temperature for plant-herbivore interactions: a meta-analysis. Glob. Change Biol. 12: 27-41. doi:10.1111/j.1365-2486.2005.01086.x. 